\title{
DOSITEJEVO VIĐENJE DALMACIJE I FENOMEN MORLAKIZMA
}

\section{Marko Šarić}

\author{
UDK: 821.163.41Obradović, D.:314(497.5-3 Dalmacija)“17“
}

Sažetak: Polazeći od teorijskih postavki historijske imagologije autor analizira predodžbe Dositeja Obradovića o Dalmaciji i njenom morlačkom stanovništvu u unutrašnjosti. Kao središnji problem postavlja se pitanje koliko su mentalni stavovi prosvjetiteljske epohe i specifični sociokulturni konteksti prostora „morlačke“ Dalmacije, posebno njene srpskopravoslavne sastavnice, utjecali na Dositejevo stvaranje i oblikovanje slika i predodžbi o zemlji i narodu. U tom razmatranju postoje zapravo dva Dositeja: „mladi“ iz dalmatinskog razdoblja koji je još uvijek pod utjecajem crkvene tradicije, i „zreli“ iz kasnijeg vremena, koji je već usvojio ideje prosvjetiteljskog doba. Većina Dositejevih predodžbi potječe iz zrelijeg razdoblja i u funkciji su njegova tada već potpuno izgrađenog prosvjetiteljsko-racionalističkoga vrijednosnog sustava. Višeslojnost njegovih pogleda na Dalmaciju ogleda se u kritici tri vrste fenomena: kritici praznovjerja i običaja morlačkog puka, kritici religijske kulture i vjerske nesnošljivosti među Morlacima „grčkog“ $i$ „latinskog“ vjerozakona, te u kritici uloge koju običaji imaju u formiranju pojedinca i kulture uopće. Dositej ne slijedi u svemu književni diskurs morlakizma koji tada dominira u europskoj prosvjetiteljskoj literaturi. U dalmatinskim Morlacima ne prepoznaje „plemenite divljake“, nego plemenite priproste ljude, ne „otkriva“ egzotičan narod, već vlastiti (,slavenosrpski“) narod koji želi podučiti i osvijestiti u prosvjetiteljskom duhu. Ono što ga najviše veže uz morlakistički diskurs jest umjerena idealizacija stanovnika dalmatinske unutrašnjosti: to su pravdoljubivi i pošteni ljudi, ali ih neprosvijećenost i praznovjerje čini zaostalim u svakom pogledu. Prema Morlacima ima ambivalentan odnos: o njima katkad piše s pozicije sunarodnjaka (Mi-odnos), a ponekad kao o Drugima, drukčijima od sebe (Oni-odnos), naročito u slučaju kritike običaja i praznovjerja. Kao poseban problem ističe vjersku nesnošljivost, ali izvor tome vidi u crkvenim krugovima, napose monaštvu, a ne u narodu, što ga čini bliskim Fortisu i Lovriću.

Ključne riječi: Dositej Obradović, prosvjetiteljstvo, historijska imagologija, Mletačka Dalmacija, Morlaci, morlakizam.

D

oravak Dositeja Obradovića u Dalmaciji, „odakle je počeo otkrivati Mediteran“ u čijem je „kulturnom miljeu stekao čvrstu intelektualnu osnovicu“, kako to rezimira Radovan Kovačević u svojoj popularno pisanoj monografiji o Dositeju Obradoviću na Sredozemlju, ${ }^{1}$ vezan je ponajprije za morlačku srpskopravoslavnu sredinu Kninske krajine i Tromeđe. Ta u XVIII. stoljeću zaostala i u svakom pogledu zapuštena sredina na paradoksalan je način asocijativno djelovala na intelektualno sazrijevanje mladoga odbjegloga 
hopovskog jeromonaha, ostavivši dubok trag u njegovim djelima, od kojih su prva četiri (Bukvar, Ižica, Hristoitija, Venac od alfavita) rezultat upravo njegova dalmatinskog iskustva. Dalmacija je tako zauzela važno mjesto u njegovu životu, obilježenom traganjem za jedinstvenim jezičnim i nacionalnim sustavom koji nadilazi vjerske razlike te za društvenim i individualnim usavršavanjem temeljenim na racionalističko-prosvjetiteljskim osnovama. Sintetizirajući osnovne ideje europskog prosvjetiteljstva i multikulturno nasljeđe „cělogo Ilirika“ - pa tako i Dalmacije - Dositej je koncem XVIII. stoljeća položio temelje modernoj (svjetovnoj) srpskoj kulturi. To u punom smislu potvrđuje i njegov književni rad, koji je najvažniji primjer prosvjetiteljske književnosti u Srba, ali danas znači više kulturno-povijesnu nego književnu baštinu. ${ }^{2}$

Razmatrajući temu Dositejeva viđenja Dalmacije, u kojoj je s prekidima boravio cijelo jedno desetljeće (1761-1771), i njenog morlačkog stanovništvu u unutrašnjosti, kao središnji problem postavlja se zapravo pitanje koliko su mentalni stavovi jedne epohe (to jest prosvjetiteljstva) i specifični sociokulturni konteksti jednoga prostora (to jest „morlačke“ Dalmacije), utjecali na Dositejevo stvaranje i mijenjanje slika i predodžbi o drugima - zemlji ili narodu - ali i o samome sebi. Metodološki rečeno, u takvu tipu istraživanja nužno je dotaknuti se imagologije, odnosno kretati se, da tako kažemo, skliskim područjem Dositejeve literarne uobrazilje. ${ }^{3}$ Drugim riječima, potrebno je ustanoviti koliko u njegovim predodžbama Dalmacije i morlačkih gorštaka ima iskustvenoga, a koliko zamišljenoga, odnosno imaginarnoga i realnog sagledavanja prostora i ljudi. Pri tome je posebno važno ispitati i moguće intertekstualne aspekte takvih predodžbi, posebno kad je riječ o diskursu morlakizma kao onodobne europske književne mode ili, još i više, u slučaju starog i novog shvaćanja jezika i narodnosne zajednice, društva i tradicije u „slavenosrpskoj“ i široj „ilirskoj“ prosvjetiteljskoj literaturi XVIII. stoljeća. Zapravo, problematiku Dositejvih predodžbi, kao uostalom i cjelokupno njegovo djelo, potrebno je promatrati u kontekstu srednjoeuropskog prosvjetiteljstva (Aufklärung), to jest klasicizma i predromantizma, napose njihovih epistemoloških i etnografskih aspekata, pri čemu, dakako, ne treba izostaviti ni tek stasalu slavističku znanost i njezine jezično-(proto)nacionalne koncepcije i konstrukcije. Takvu bi analizu nadalje trebalo povezati i s povijesnim kontekstima, to tim više jer je srpsko građansko društvo u usponu tijekom XVIII. stoljeća - čiji je vodeći „glasnogovornik " bio upravo Dositej Obradović - otkrivalo sebe i svoju nacionalnu prošlost ponajprije posredovanjem književnosti; književnom je djelu naime bila dodijeljena uloga da „rekapitulira opće istine o iskustvu naroda“" ${ }^{4}$

Svaka je predodžba u dobroj mjeri određena položajem promatrača spram promatranog. Postavljaju se dakle pitanja tko govori, kome se govornik obraća, koje su okolnosti utjecale na piščev stav, i konačno, o kojem je tekstu, odnosno žanru riječ. Dositej, koji 1761. godine kao mladi kaluđer dolazi u Dalmaciju, i Dositej, koji 1783. kao zreli racionalistički filozof i

U književnopovijesnoj literaturi često se susreće teza da prosvjetiteljstvo, svojim pedagoškim tendencijama i populariziranjem znanosti kako bi se postigla što veća prosvijećenost, nije mnogo pogodovalo književnom razvoju.

3 Imagologija se obično definira kao istraživačka grana komparativne književnosti koja se bavi proučavanjem predodžbi o stranim zemljama i narodima, ali i o vlastitoj zemlji i narodu, ponajprije u književnosti, ali i na drugim područjima, primjerice u publicistici, slikarstvu, filmu, historiografiji itd. Općenito o polazištima i ciljevima imagologije kao znanstvene discipline, njezinom predmetu i metodama istraživanja, primjeni i rezultatima, više pogledati u: Vladimir GVOZDEN, „Polazišta i ciljevi imagološkog proučavanja književnosti.“, Zbornik Matice srpske za književnost i jezik, vol. 49/2001., br. 1-2, 212-224.; Davor DUKIĆ, „Predgovor: O imagologiji.”, Kako vidimo strane zemlje. Uvod u imagologiju (priredili: Davor Dukić, Zrinka Blažević, Lahorka Plejić Poje, Ivana Brković), Zagreb 2009., 5-22.

4 Mirjana D. STEFANOVIĆ, „Čemu istoriografija u 18. stoleću.“, Istraživanja (Novi Sad), br. 21/2010., 126. 
prosvjetiteljski reformator počinje objavljivati svoja kapitalna djela, nije u duhovnom smislu sasvim ista osoba. ${ }^{5}$ Većina predodžbi o Dalmaciji i Morlacima potječe zapravo iz njegova zrelijeg razdoblja i u funkciji su njegova tada potpuno izgrađenog prosvjetiteljsko-racionalističkoga vrijednosnog sustava. Dositejev književni rad bio je pak namijenjen svakome „koji razumeva naš jezik" bez obzira na vjersku pripadnost. U tom smislu on se i stanovništtvu Dalmacije (obje vjeroispovijesti) primarno obraćao kao sunarodnjacima i „istojezičnicima“, što ga čini bitno različitim od književnih mu suvremenika „morlakista“, čija je čitalačka publika bila znatno šira, internacionalna i europska, i koji su se ponajmanje obraćali glavnim protagonistima - Morlacima u Dalmaciji. Suštinu morlakističkog diskursa čini zapravo književna slika stranoga, odnosno nova, prosvjetiteljska interpretacija drugosti, koja je istodobno bila u funkciji propitivanja i (re)interpretacije vlastita identiteta, izražena "starim“ jadranskim binarnim oprekama (metropola - provincija; jadranski grad - dinarsko selo; maritimno priobalje - pastoralno zaleđe) i novima, u duhu prosvjetiteljske etike (civilizacija - divljaštvo, kultura - priroda, napredan - zaostao, povijesno - nepovijesno, Zapad - Istok). U Dositejevim djelima takvih dihotomija ili nema ili su iskazivane u sasvim drukčijem kontekstu. Postavlja se stoga pitanje o kojim sve kategorijama drugosti i razinama identiteta možemo govoriti u Dositejevoj književnoj konstrukciji i reprezentaciji dalmatinskoga morlačkog podneblja. Činjenica je naime da on o dalmatinskom stanovništvu, a tu se prije svega misli na njegovu morlačku sastavnicu, piše s pozicije sunarodnjaka (Mi-odnos), ali ponekad o njima piše i kao o Drugima, drugačijima od sebe (Oni-odnos). Ponekad govori i piše s pozicija autopredodžbi Morlaka, a ponekad pak sa suprotne promatračke pozicije, naročito kad je u pitanju kritika običaja i praznovjerja. Konačno, putopisi i memoaristika - toliko karakteristični za književnost prosvjetiteljstva - tipovi su teksta u kojima se najčešće pojavljuju predodžbe o narodima i zemljama odnosno stvaraju slike o Drugom i slike o Sebi, što u punom smislu potvrđuje i Dositejev opus. U njegovu slučaju tu su još i pisma, basne i eseji.

\section{I.}

U nepreglednoj bibliografiji o Dositeju Obradoviću u srpskoj historiografiji, kao i u drugim znanstvenim disciplinama, ${ }^{6}$ o dalmatinskim kontekstima njegova života i djela postoje

5 Duhovni razvoj Dositeja Obradovića obično se promatra u okviru pet kronoloških etapa: prva (od rođenja do 1760. godine) koju karakterizira mladenačka težnja za stjecanjem znanja i želja da postane kaluđer i živi posvećenim životom. Druga etapa (1761.-1771) obuhvaća Dositejev boravak u Dalmaciji i Sredozemlju (Crna Gora, Grčka, Mala Azija, Albanija, Venecija). To je razdoblje stjecanja klasičnog obrazovanja, učenja jezika (latinski, talijanski, grčki) te početak kritičkog preispitivanja. Treća etapa (1771.-1782) ključna je za usvajanje racionalističkih i prosvjetiteljskih ideja koje Dositej, uglavnom kao samouk, upoznaje i usvaja tijekom putovanja i školovanja po Srednjoj Europi (Beč, Modra, Požun). Četvrta etapa (1782.-1806) razdoblje je Dositejeve umne i fizičke zrelosti u kojem nastupa kao racionalistički filozof i prosvjetiteljski reformator. To razdoblje počinje njegovim dolaskom u Halle na Saali, gdje skida svećeničku „odeždu“ i oblači „grešne svetske aljine“, i obilježeno je snažnim intelektualnim angažmanom te objavljivanjem kapitalnih djela i, dakako, opet brojim putovanjima po Europi (Pariz, London, Beč, Trst, Venecija), a završava odlaskom u ustaničku Srbiju. Posljednja, peta etapa (1806.-1811) vrijeme je Dositejeva praktičnog političkog djelovanja u Karađorđevoj Srbiji, ponajprije prosvjetnoga i diplomatskog (postaje ravnatelj svih srpskih škola, izabran za člana Praviteljstvujuščeg sovjeta, otvara Veliku školu, odlazi u diplomatske misije). U tom periodu nije pisao važnija djela, već samo pjesme, prigodne govore i, konačno, oporuku.

6 Iscrpni pregled svih relevantnih radova o Dositeju Obradoviću nalazi se u: Dositej OBRADOVIĆ, Sabrana dela Dositeja Obradovića. (ur. Mirjana D. Stefanović), knjiga 6, Beograd 2008. 
oprečna mišljenja i vrednovanja. ${ }^{7}$ Najčešće se susreće ocjena da boravak u Dalmaciji, gdje je počeo djelovati kao književnik, a na određeni način i kao reformator, čini sudbonosnu prekretnicu u njegovu prosvjetiteljskom i nacionalnom usmjerenju. Istraživači su se pritom pozivali na samog Dositeja koji u autobiografskim putopisima, esejima i pismima navodi da je u Dalmaciji primio najljepše životne lekcije i položio temelj svojem „svemu sljedujućem [...] življenju“" ${ }^{8} \mathrm{U}$ tom smislu, prema većini istraživača, u toj su se pokrajini rodile i tri glavne poruke njegova djela: o vjerskoj toleranciji, o odnosu vjere, jezika i roda, te o nužnoj potrebi prosvjećivanja na narodnom jeziku. ${ }^{9}$ Međutim Dositejeva se aktivnost u Dalmaciji nerijetko i preuveličavala, pri čemu nisu nedostajala ni pretjerivanja, poput tvrdnje da je dalmatinska sredina na njega više utjecala nego Diderot, Rousseau i Voltaire zajedno. Takve neumjerene ocjene najčešće su se doticale teme o počecima njegova književnog rada na narodnom jeziku. ${ }^{10}$ Ništa manje problematičnima djeluju i smjele tvrdnje o Dositeju kao

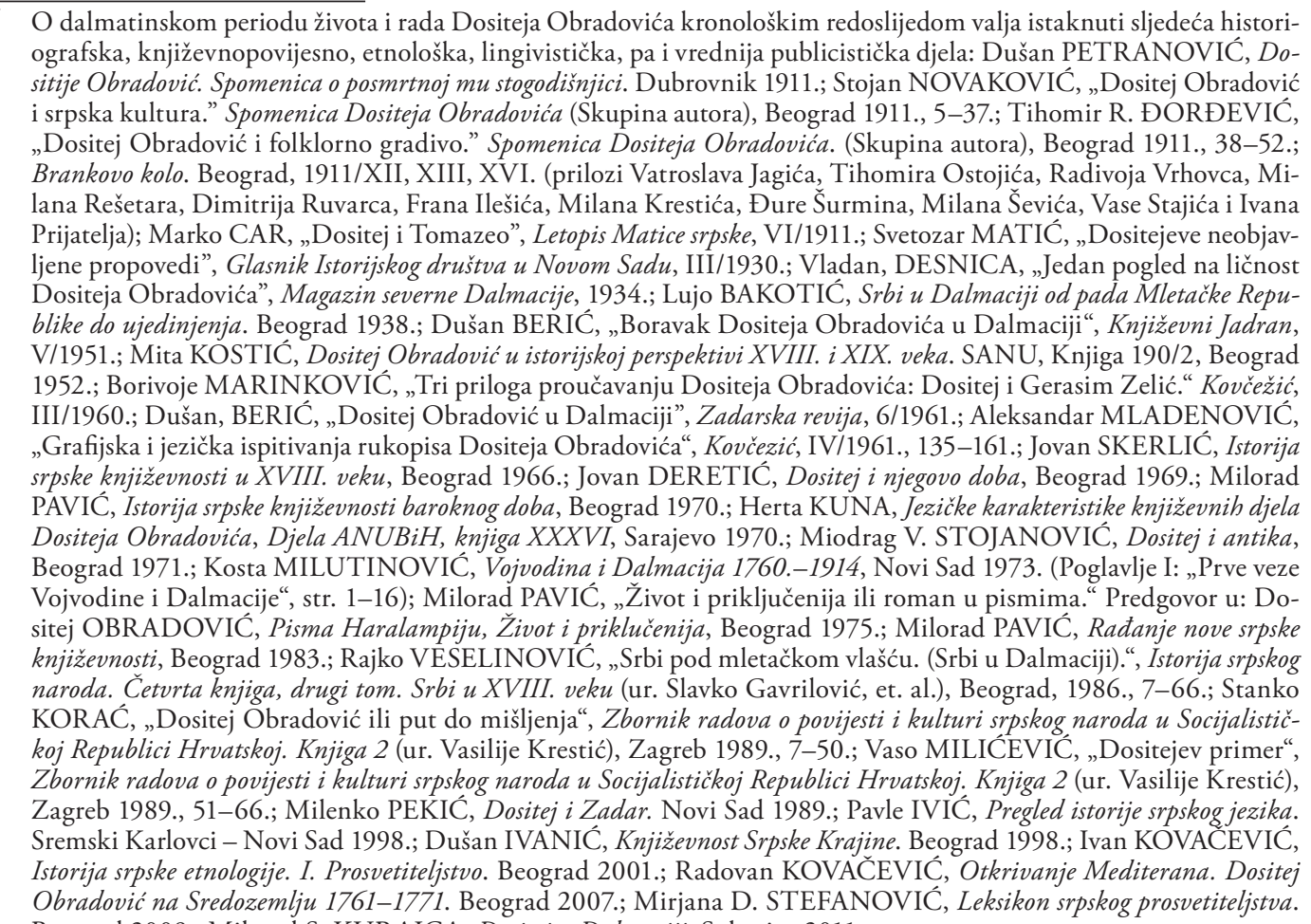
Beograd 2009.; Milorad S. KURAICA, Dositej u Dalmaciji. Subotica 2011.

8 „Tri godine po pogodbi mojem provedem s onim božijim ljudima, [to jest u Dalmaciji, op. a.] tri mile godine koje vsegda s uslaždenijem srca spominjem i koje sam za osnovanije svemu sljedujućemu mojemu življenju položio; zašto sam u njima ne samo opitom poznao i naučio nego i u jestestvo sebi pretvorio kako čovek u niskom sostojanju može s malim zadovoljan, dobar i blagopolučan biti.“ Dositej OBRADOVIĆ, Život i priključenija, Beograd 1989., 114.

9 Mirjana D. Stefanović ovako sažima Dositejeva iskustva iz Dalmacije i utjecaj te sredine na njegovo sazrijevanje: „,...] Dositej se rado seća tog boravka tokom kojeg je počeo da piše i prve bukvarske knjige i hrišćanski priručnik o lepom vaspitanju i da beleži narodne izreke. Tu je učio i matematiku, iz manastirskih biblioteka uzimao knjige za čitanje, upoznao srpsku kulturu na izvoru i u kasnijim sećanjima nostalgično se prisećao lepih trenutaka. Valjda mu se tu, i među nekim već pounijaćenim Srbima, rodila ideja o toleranciji, o odnosu vere, jezika i roda i o nasušnoj potrebi čitanja i obrazovanja. Bez obzira na to što je Dalmacija najkasnije dobila svoje srpske škole, u njoj je živeo onaj element srpstva koji Dositej nije tako čistim video u Temišvaru. Moguće je da je tu čuo i mnoge narodne pesme koje je kasnije navodio u svojim delima." (Mirjana D. STEFANOVIĆ, Leksikon srpskog prosvetiteljstva, 81).

10 Riječ je o Dositejevu kratkom boravku u kući prote Avrama Simića u Orliću, gdje mu se, udovoljavajući želji protinoj najstarijoj kćeri Jeleni, rodila želja da počne pisati knjige „prosto srpski“: „Ovo je privi povod i uzrok da se u meni 
inicijatoru prvih veza između vojvođanskih i dalmatinskih Srba ili pak teza o „prvom srpskom piscu iz Dalmacije“. ${ }^{11}$ Nasuprot tome, u jednom manjem, ali ipak utjecajnom dijelu srpske historiografije, Dositejeva se uloga u Dalmaciji i minorizirala. ${ }^{12}$ Takvo gledište nadasve se primjećuje u krugu autora koji su svjetonazorski bliski stavovima konzervativnijeg dijela srpskopravoslavne crkve, a koji Dositeju ne mogu oprostiti odvajanje i udaljavanje nacionalne kulture od crkve, odnosno raskid sa „svetosavskom tradicijom“. Znakovita je u tom smislu „šutnja“ episkopa Nikodima Milaša, glavnog autoriteta za povijest pravoslavlja, a time i Srba u Dalmaciji na prijelazu iz XIX. u XX. stoljeće, koji u kapitalnom djelu Pravoslavna Dalmacija (Novi Sad, 1901) Dositeja uopće ne spominje, pa čak ni u poglavlju o pitanju pravoslavnih škola u Dalmaciji XVIII. stoljeća, gdje je uloga „hopovskog didaskala“ ipak bila nezaobilazna.

U hrvatskoj pak historiografiji o Dositejevu boravku u Dalmaciji jedva da uopće ima spomena. Osim sporadičnih usputnih obavijesti ne postoji zapravo nijedan cjeloviti rad ili osvrt na tu temu. Nezainteresiranost hrvatskih povjesničara za istraživanje boravka utjecajne srpske povijesne ličnosti u jednoj od hrvatskih povijesnih pokrajina na pragu moderne epohe tek se djelomično može objasniti etnocentrističkim „mentalitetom“, koji prosuđuje prošlost isključivo sa svoga nacionalnog stajališta i nije sposoban za interkulturnu perspektivu i širu kontekstualizaciju vlastite povijesti. Bit će da je izostanak nacionalno motivirane polemike s dositejevskim idejama - za razliku od recimo vukovskih - možda i glavni razlog takve nezainteresiranosti. Mnogo bolje nije ni u drugim znanstvenim područjima, pa se može zaključiti da je Dositejev boravak u Dalmaciji danas široj hrvatskoj kulturnoj javnosti gotovo nepoznata činjenica. ${ }^{13}$

Što se Dositejeva kulta u sjevernoj Dalmaciji tiče, on u nejednakom intenzitetu traje već nepuna dva stoljeća te se u različitim oblicima iskazivao u građanskoj (intelektualnoj) sredini i narodnoj predaji dalmatinskih Srba. ${ }^{14} \mathrm{U}$ svakom slučaju, u nepomućenom kontinuitetu traje od 1911. godine, kada je i u Dalmaciji svečano obilježena stota obljetnica njegove smrti. Izraženo štovanje Dositeja Obradovića u Dalmaciji začelo se još u krugu pokretača lista Srpsko-dalmatinskij magazin: ljubitelj prosveštenija, koji je izlazio u Zadru od 1836. do 1848. Urednici toga lista, Božidar (Teodor) Petranović i Đorđe Nikolajević, mogu se - nakon Gerasima Zelića, Jovana Bovana, a u određenom smislu i Pavla Sola-

velika želja začne i rodi da mi samo dotle Bog daruje život dok što srpski na štampu izdam i prekrasnim kćerima i sinovom roda mojega soopštim. “ (D. OBRADOVIĆ, Život i priključenija, 116). Taj početak njegova književnog rada na narodnom jeziku različito se tumači, pri čemu neki idu tako daleko da ističu kako je Avramova kći Jelena Simić na „Dositeja više uticala nego Didro, Ruso i Volter skupa!“ (usp. Dragić VITOŠEVIĆ, Do Evrope i natrag I, Gornji Milanovac 1987.).

11 Usp. Kosta MILUTINOVIĆ, Vojvodina i Dalmacija 1760.-1913., 3; KORAĆ, Stanko. „Dositej Obradović ili put do mišljenja“., 23.

12 Usp. Marko JAČOV, Venecija i Srbi u Dalmaciji u XVIII. veku, Šibenik 1987., 119.

13 Među rijetkim iznimkama treba spomenuti hrvatskog filologa i povjesničara književnosti Vatroslava Jagića i Đuru Šurmina, koji su povodom stogodišnjeg jubileja Dositejeve smrti 1911. napisali više prigodnih članaka o njegovu boravku u Dalmaciji. Šurmin je u jednom od njih naglasio kako je „Dalmacija kolijevka Dositiju kao književniku“ kao i sljedeće: „On, prosvjetitelj i prvi učitelj Srba, poče baš da književnikuje u Dalmaciji. Dalmaciji je suđeno da vodi prvo kolo kod počinjanja i preporađanja Hrvata i Srba. Obradović joj sam zahvali za prve pobude pisanja narodnim jezikom.“ Usp. Đuro ŠURMIN, „Dositije Obradović u Dalmaciji“, Jug, br. 4/1911.; usp. i Kosta MILUTINOVIĆ, Vojvodina i Dalmacija 1760.-1914., 10.

14 Stojan Novaković iznosi 1911. godine zanimljivu primjedbu prema kojoj su prosvjeta i nova narodna književnost koje je utemeljio Dositej znatno više proniknuli u kulturnoj sredini Srbije negoli među prečanskim Srbima u Monarhiji. U tom smislu je, prema njegovu mišljenju, i Dositejev lik postao popularniji, „takoreći svemogućan“ u Kraljevini Srbiji za razliku od „prečanskih krajeva“ (Stojan NOVAKOVIĆ, „Dositej Obradović i srpska kultura.“, 36). 
rića ${ }^{15}$ - smatrati drugom generacijom Dositejevih učenika i sljedbenika u Dalmaciji. ${ }^{16} \mathrm{Me}-$ đutim u drugoj polovici XIX. stoljeća, kako su se (re)afirmirali religijski i konfesionalni čimbenici u formiranju nacionalnog identiteta dalmatinskih Srba, uspomena na Dositejev prosvjetiteljski i književni rad pomalo je jenjavala. Početak XX. stoljeća donio je novu klimu suradnje u srpsko-hrvatskim odnosima u Dalmaciji (Zadarska rezolucija) kao i slabljenje klerikalnih političkih pozicija na objema stranama, što se na poseban način odrazilo i na afirmaciju dositejevske ostavštine. ${ }^{17}$ Ona je buknula novom snagom upravo 1911. u okviru općenarodne Dositejeve proslave povodom stogodišnjice njegove smrti, kada su se dalmatinski Srbi, kako to ističe Kosta Milutinović, „ponovo sjetili“" tog narodnog prosvjetitelja. ${ }^{18}$ Važnu ulogu u promicanju Dositejeva kulta imali su tada pojedinci iz političkih i intelektualnih (pa i crkvenih) krugova dalmatinskih Srba, poput političara Luje Bakotića, književnika Marka Cara ili svestranog Danila Petranovića, zavičajem Plavanjca i rođaka „prvog Dositejevog branioca“ u Dalmaciji Božidara Petranovića, koji je povodom stogodišnjega jubileja objavio knjigu o Dositejevom boravku i radu u Dalmaciji. ${ }^{19}$ Petranović je pritom s pravom ukazao kako je Dositej presudno utjecao na intelektualno formiranje i razvoj srpskoga građanskog sloja u Dalmaciji. ${ }^{20}$ Dositejev kult posebno je njegovan u mjestima Kninske krajine i Tromeđe u kojima je boravio kao učitelj i propovjednik (Kninsko Polje, Golubić, Orlić, Plavno). Njegov lik „narodnog učitelja i mudraca“ u pučkoj je interpretaciji poprimio legendarno, gotovo svetačko obilježje, a mjesta u kojima je boravio ili kuda je prolazio postala su svojevrsni loci memoriae, izvorišta lokalnog i nacionalnog identiteta sjevernodalmatinskih Srba. ${ }^{21}$

15 Pavle Solarić (1779-1821) slovio je za najdražeg Dositejeva učenika, a prema Jovanu Skerliću bio je „posljednji među glavnim piscima Dositejeve škole“. Premda je rođen u Velikoj Pisanici na Bilogori, u vojnokrajiškoj Hrvatskoj (Varaždinski generalat), njegova dugogodišnja književna, izdavačka i prevodilačka djelatnost u Veneciji i Trstu posredno ga je povezivala is dalmatinskim krugom srpske svećeničke i građanske inteligencije u nastajanju.

16 U tome se posebice isticao Božidar Petranović koji je 1845. i 1846. vodio zanimljivu polemiku s Niccolom Tommaseom o Dositejevim društveno-političkim i moralno-filozofskim idejama (Kosta MILUTINOVIĆ, Vojvodina i Dalmacija 1760.-1914., 10-14).

17 Kosta Milutinović u tom smislu zaključuje: „Više još, u formiranju i idejnom izgrađivanju Narodne stranke, prve zajedničke političke grupacije Srba i Hrvata u primorskim zemljama, ima pozitivnih komponenata dositejevskih tradicija: bratstvo južnoslovenskih naroda bez obzira na verske razlike i nacionalne specifičnosti. Nosioci pravoslavnog klerikalizma na Jadranu bili su antipodi Dositeju. Ali - zato su se sastavljači Riječke i Zadarske rezolucije i začetnici politike novog kursa ponovo obratili na dositejevske pozicije i aktivno učestovoali u rušenju Habsburške Monarhije i udaranju prvih temelja budućoj južnoslovenskoj zajednici izvan austrijskih okvira." (Isto, 16).

18 Isto, 14.

19 Danilo, PETRANOVIĆ, Dositije Obradović. Spomenica o posmrtnoj mu stogodišnjici. Dubrovnik 1911., 1-50.

20 „Naročito onaj naš srednji stalež, koji je uz Dositija najviše bio pregao, i koji ga smatraše svojim narodnim mudracem i učiteljem, stade po svima krajevima da osniva zadužbine, potpomaže srpsku knjigu kao i razvitak narodne prosvjete. Njegovim potstrekom bez sumnje je i Jovan Bovan, osnovalac srpske muške osnovne škole u Šibeniku, ostavio ovu korisnu zadužbinu svome narodu još u početku XIX vijeka. U prilog ovome ističe se sastajanje i općenje Bovanovo u Skradinu, a po svoj prilici i u Mlecima." (Isto, 46-48.)

21 Plavno, selo u srcu Tromeđe u sjevernoj Dalmaciji, posebno se ističe takvim mjestima sjećanja na svoga ,prvoga plavanjskog učitelja“, kao što je „Bratska kuća“, u kojoj je bila škola i u kojoj je Dositej napisao svoju Ižicu, ili „Dositejev hrast", pod kojim je, prema jednoj varijanti seoske predaje, Dositej ljeti podučavao djecu, a prema drugoj, koji je upravo on i zasadio. (Danilo PETRANOVIĆ, Dositije Obradović. Spomenica o posmrtnoj mu stogodišnjici., 38-39.; Danko PERIĆ. „Zdravo... buntovno mjesto; Plavno u istoriografiji i literaturi“, Plavno - monografija. Beograd, 2008., 100-107.) 
Dositejev boravak u morlačkoj Dalmaciji, koji je s prekidima trajao od 1761. do 1771, dogodio se neposredno uoči famoznoga „otkrića Morlaka“ padovanskog opata Alberta Fortisa, što se itekako osjeća i u njegovim djelima, autobiografsko-putopisnom Životu i priključenijima i Sovjetima zdravago razuma. Premda navedena djela nastaju između 1783. i 1788. godine, u vrijeme kada je literarna „morlačka moda“ već uvelike osvojila europsku prosvjetiteljsku javnost, u njima nema traga konceptu „plemenitog divljaka“ koji čini osnovu morlakističkog diskursa, niti se pojam „Morlak“ uopće koristi. Dositej je svakako bio dobro upoznat s tim pomodarskim pokretom, uostalom on je u Mezimcu (posthumno objavljenom 1818) i preporučivao „srpskoj junosti“ da čita Defoeov roman Robinson Crusoe, paradigmatsko djelo kad je riječ o spomenutom konceptu. ${ }^{22}$ Međutim činjenica je isto tako da Dositej nije u svemu slijedio rusoovske koncepcije. Premda su elementi rusoovskog kulta prirode prisutni u nekim njegovim djelima, kao primjerice u „naravoučeniju“ jedne basne iz 1788. godine, gdje anticipira ono što bi danas nazvali „zaštitom prirode“, u slučaju postanka društva i njegova razvoja Dositej se jasno distancirao od koncepcije prirodnog stanja francuskog prosvjetitelja te je u tom pogledu bio znatno bliži Hobbesovu shvaćanju „prvobitnog barbarstva“. ${ }^{23} \mathrm{U}$ tom smislu ni kult prirode, u kontekstu diskursa o prirodnom čovjeku neiskvarenom civilizacijom, koji se kao središnji motiv javlja u većini tadašnjih djela koja tematiziraju morlački život i običaje, nije našao mjesto u njegovu opusu. Dositeju je taj književni postupak bio jednostavno neprikladan jer u dalmatinskim Morlacima, kao što ćemo vidjeti, nije gledao kulturnu drugost, a još manje egzotiku dalekih krajeva. ${ }^{24} \mathrm{U}$ tom smislu nije upotrebljavao ni pojam „Morlak“ koji nikad nije bio prihvaćen u puku. Riječ je o talijanskom (mletačkom) terminu koji je postao povijesnom oznakom za one zajednice vlaškog kulturno-povijesnog kruga koje su živjele pod Venecijom ili su s njom dolazile u bliži kontakt. ${ }^{25}$

Problematizirajući temu Dositejeva viđenja Dalmacije i njenoga morlačkog stanovništva u unutrašnjosti, potrebno je početi od činjenice da u tom razmatranju postoje zapravo dva Dositeja: „mladi Dositej“ iz dalmatinskog razdoblja („mladi i maleni kaluđer“, kako

22 D. OBRADOVIĆ, Dela Dositeja Obradovića. Peto, državno izdanje. (ur. Jovan Skerlić; Milutin Dragutinović; Miloš Ivković), Beograd 1911., 438.; Robinson Crusoe Daniela Defoea preveden je na slavenosrpski i 1799. objavljen u Budimu (Marko KRSMANOVIĆ, „Robinson u nas [Povodom stopedesetogodišnjice prvog srpskog prevoda]“, Nastava jezika i književnosti u srednjoj školi, God. I, sv. 1-2/1950.).

23 Milorad. PAVIĆ, „Srpska književnost predromantizma.“, Istorija srpskog naroda. Četvrta knjiga, Drugi tom, Srbi u XVIII veku (ur. Slavko Gavrilović, et al.), Beograd 1986., 230-232.; Ivan KOVAČEVIĆ, Istorija srpske etnologije. I. Prosvetiteljstvo., 60. O „rusoizmu“ kod Dositeja Obradovića, Mirjana D. Stefanović bilježi sljedeće: „Odjeci shvatanja Denija Didroa i Rusoa o tome kako je čovek po svojoj prirodi dobar rasuti su po celokupnom Dositejevom opusu, ali na nešto drukčiji način. Naš pisac, naime, ne upoređuje niti suprostavlja dobro i zlo u običajima prirodnog i civilizovanog čoveka. Uvek je uveren u to da čovek postaje i mora da postane umniji, slobodniji i srećniji usavršavajući se u samom društvu, utičući recipročno i na svoje okruženje, a ne bežeći u prirodu. Iako filosof rusoovskog pravca, ne neguje njegov anarhizam, što je izrazito vidljivo u Sobraniju, ne podleže kultu Rusoa, već ideju dobrog i slobodnog čoveka zasnovanu na rusoovskom idealu preokreće u lični izraz sreće koja se ostvaruje i u komunikaciji s Drugim, ostavljajući tako ideje koje će se razviti u srpskom predromantizmu." (Mirjana D. STEFANOVIĆ, Leksikon srpskog prosvetiteljstva., 197-198).

24 Pravi prodor književnosti o „plemenitom divljaku“ u srpskoj sredini dogodit će se tek u prvoj polovici XIX. stoljeća i uglavnom je vezan uz kazališnu i prevodilačku djelatnost Jaokima Vujića. O tome više u: Ivan KOVAČEVIĆ, Istorija srpske etnologije. I Prosvetiteljstvo., 225-242.

25 Marko ŠARIĆ, „Planine i morlački svijet u Dalmaciji: ekohistorijski osvrt,“ Ekonomska i ekohistorija: časopis za gospodarsku povijest i povijest okoliša, Vol. 6, No. 1/2010., 55-94. 
je sam sebe jednom opisao) i „zreli Dositej“ iz kasnijeg razdoblja koji je već upio prosvjetiteljske ideje svoga vremena. Slučaj je htio da su njegova najranije napisana djela, poznatija kao „spisi iz Dalmacije“, objavljena najkasnije, i to posthumno: djela Hristoitija sriječ blagi običaji i Venac od alfavita (dovršena u Skradinu 1770. i 1771) objavljena su u Budimu 1826. godine, Prvenac - Ižica ili Dositejeva bukvica (dovršena u Plavnom 1770), objavljena je u Karlovcu 1830, dok je Dositejev književni prvijenac, takozvana prva Bukvica, napisana još 1765 . godine u Orliću, kasnije izgubljena i nikad nije objavljena. Takva kronološka inverzija uvjetuje i retrospektivni pristup u istraživanju Dositejevih predodžbi o Dalmaciji i njenom stanovništvu.

Pišući svoje prve radove u Dalmaciji, Dositej je nedvojbeno još uvijek bio kršćanski teološki pisac pod snažnim utjecajem srpske pravoslavne tradicije. ${ }^{26} \mathrm{O}$ njegovu tadašnjem svjetonazoru, između ostalog, svjedoče i zapisi na knjigama pronađeni u knjižnici manastira Dragovića, od kojih se na jednoj po običaju srednjovjekovnih čitatelja potpisao kao „grešni Dositej Hopovski““ ${ }^{27}$ Taj se svjetonazorski sustav, dakako, odrazio i na njegov prvi doživljaj Dalmacije i morlačkog srpskopravoslavnog stanovništva, koje primjerice u Ižici, koristeći teološki pojam - božji ljudi - primarno promatra kao duhovnu pastvu. Dositej će kasnije u Životu i priključenijima uz tu sintagmu koristiti i novu - dobri ljudi - u kojoj se već očituju nove duhovne i književnostilske tendencije XVIII. stoljeća: racionalističko prosvjetiteljstvo i sentimentalizam. ${ }^{28}$ Važno je ipak naglasiti da je prilikom trećeg boravka u Dalmaciji, od ljeta 1769. do jeseni 1771, nakon povratka iz Smirne gdje je stekao klasično obrazovanje na antičkim (grčko-rimskim) i bizantskokršćanskim izvorima, Dositej postao, rekli bismo, u opservacijama Dalmacije profaniji i kritičniji. Naime tada zapaža i neke loše osobine „božjih“" odnosno „dobrih" ljudi, a na jednom mjestu gotovo rezignirano primjećuje: „Ništa ti nejma da valja u ovoj našoj Dalmaciji.“ ${ }^{\text {“2 }}$ Ta postupna duhovna preobrazba dogodila se pod utjecajem, kako kaže, ,jelino-grečeske nauke“ i naročito je izražena u ideji poleznosti (korisnosti), koja će postati jednim od njegovih najvažnijih životnih načela. Valja podsjetiti da Dositej upravo po povratku iz Smirne otkriva u potpunosti svoju tolerantnu prirodu, ne samo u religijskom već i u širem, antropološkom smislu. To je kršćanska snošljivost „erazmovskoga tipa“, samilost prema ljudskim nevoljama i slabostima, u kojoj još nema kritike crkvenih struktura. Iz Hristoitije izbija jasan odnos prema Drugome: on je taj kojeg treba poštovati i bez kojeg nije moguća komunikacija među ljudima - ,ja i drugi u ravnopravnom su odnosu“. ${ }^{30}$ U Vencu od alfavita javljaju se i središnji pojmovi njegova kasnijeg prosvjetiteljskog djelovanja: sloboda, razum, i već spomenuta poleznost. ${ }^{31}$ To mjesto otvara važno pitanje: otvara li se Dositej prema prosvjetiteljstvu već u Dalmaciji, nakon povratka iz Grčke, i počinje li na neki način djelovati kao reformator ili je možda naknadno,

$\overline{26}$ Po formi i po idejama, kako je to utvrdio još Jovan Deretić, ta djela predstavljaju nastavak crkvene tradicije. Dositej tada još nije bio upoznao i usvojio europsku prosvjetiteljsku misao koja će ga nadahnjivati u kasnijim djelima. Usp. Jovan DERETIĆ, Dositej i njegovo doba, Beograd 1969., 57.

27 R. KOVAČEVIĆ, Otkrivanje Mediterana. Dositej Obradović na Sredozemlju 1761.-1771., 163.

28 „Ali sam ja, i ne misleći tada o tom, od njih istih, a navlastitio od Novakovića, s kojim sam u komšiluku živio i sve praznične dne u njegovom društvu bio i provodio, nanjužnije i najlepše u životu lekcije primao, to jest lekcije nepritvornosti, čistoserdečnosti, ljubeznosti i blagonaravija. Kakovo blaženstvo i raj na zemlji s onakovim svetim i dobrim ljudima živiti! Ono su pravi sveci, a niti znadu niti misle da su." (D. OBRADOVIĆ, Život i priključenija., 113)

29 D. OBRADOVIĆ, Dela., 176.

30 Stanko, KORAĆ, „Dositej Obradović ili put do mišljenja.“, 9.

31 „Kako nije polezna sloboda bez razuma, zašto mnogokrat u veliko zlo človeka uvali, tako i razum bez slobode malo valja." (D. OBRADOVIĆ, Dela., 481). 
u zrelijoj fazi, prepravljao u prosvjetiteljskom duhu neke dijelove iz svojih ranijih dalmatinskih spisa? ${ }^{32}$ U svakom slučaju, Dositej je postupno evoluirao u racionalističkog filozofa, a godine provedene u Dalmaciji (i na Sredozemlju općenito), vezuju se uz početke njegova intelektualnoga sazrijevanja i previranja te kritičkog propitivanja, pa se možemo načelno složiti s tvrdnjom Stanka Koraća koji prepoznaje tri glavna izvorišta Dositejevih književnih početaka u Dalmaciji - „teološku misao u slikama i likovima, grčku pjesničku i filozofsku kulturu i težnju prema prosvijećenosti ““ ${ }^{33}$

U svakom slučaju, u dalmatinskom periodu kod Dositeja još nema prekida s crkvenom tradicijom, njegov identitet kreće se još uvijek u okvirima tradicionalnoga srpskog etnokofesionalizma prema kojemu se narod, odnosno „slaveno-serbskij narod našego vostočnago pravoslavlja“", kako stoji u jednoj dalmatinskoj gramati iz 1751. godine, poistovjećuje sa zajednicom jedne vjere i crkve („zakona“). ${ }^{34}$ To poistovjećivanje etnije i konfesije - srpstva i pravoslavlja - posredovanjem svojevrsne evokacije duhovnog i povijesnog naslijeđa srednjovjekovne srpske države, možda je najjasnije opisao zadarski nadbiskup Matej Karaman, koji u svom izvješću iz 1750. primjećuje da se pripadnici jedne te iste „slavenske ili ilirske narodnosti“ u Dalmaciji i širem balkanskom zaleđu nazivaju Srbima „budući da su sljedbenici vjeroispovijesti koja je nekoć bila vladajuća u Srbijii“. ${ }^{35}$ Vezano $s$ tim tradicionalnim obrascem vjerskog identiteta zanimljivo je da Dositej za boravka u Dalmaciji gotovo nigdje poimence ne spominje katolike. Njegov krug suradnika i poznanika činili su tada ponajprije pravoslavni svećenici - parosi i kaluđeri - te pojedinci iz „morlačke“ srpskopravoslavne, ali i grčke dalmatinske sredine. ${ }^{36}$ Katolici pak u pravilu ostaju anonimni, poput skradinskoga biskupa koji mu kao stranom podaniku i još $\mathrm{k}$ tomu inovjercu zabranjuje propovijedanje u Skradinu, a kojega Dositej finim sarkazmom naziva tek „blagorodnim Venecijaninom“, ${ }^{37}$ ili poput zadarskih plemića, građana i svećenika koji su dolazili slušati njegove zapažene propovijedi u zadarskoj pravoslavnoj crkvi Svetog Ilije. I uz Dositejevu već tada iskazivanu otvorenost za dijalog s latinskim svijetom, ${ }^{38}$ teško se oduprijeti dojmu da „bezimeni katolici“ u njegovim dalmatinskim spisima možda predstavljaju posljednji odjek naslijeđene

32 Jovan Deretić ističe da Dositej nije mnogo cijenio svoje književne uratke iz dalmatinskog razdoblja, a nekih dijelova se čak i stidio. (J. DERETIĆ, Dositej i njegovo doba., 57).

33 S. KORAĆ, „Dositej Obradović ili put do mišljenja.“, 16.

34 VESELINOVIĆ, „Srbi u Dalmaciji.“, 51. Usp. Nikodim MILAŠ, Pravoslavna Dalmacija, Novi Sad 1901., 398-399.; O srpskom etnokonfesionalizmu u XVIII. stoljeću Sima Ćirković ovako zaključuje: „U XVIII. veku je u reči nacija odzvanjala srednjovekovna dimenzija posebnog pravnog položaja. U srpskom slučaju on je bio utemeljen u 'privilegijama’ datim Srpskoj pravoslavnoj crkvi, pa je izgledalo da se narodnost ne može odvojiti od veroispovesti." (Sima ĆIRKOVIĆ, Srbi medu evropskim narodima, Beograd 2004., 212.). O istom fenomenu na primjeru Like u XVIII. stoljeću, gdje je situacija uvelike odgovarala onoj u Dalmaciji, više pogledati u: Marko ŠARIĆ, „Predmoderne etnije u Lici i Krbavi prema popisu iz 1712./14.“, Identitet Like: korijeni i razvitak. Knjiga I. (ur. Željko Holjevac), ZagrebGospić, 2009., 340-343., 357-359.

35 „[... ] eglino sono, o Bulgari, o Serviani, o Bosnesi, o Dalmatini, sovvertiti dai monaci del medesimo rito; tutti Slavi ed Ililirici, perchè tutti d una stessa nazione slava, ed illirica, denominati Serviani, perche seguaci del rito una volta dominante nella Servia." (Nikodim MILAŠ, Documenta spectantia historiam orthodoxae Dalmatiae et Istriae a XV usque XIX saeculum. Vol. I, Jaderae 1899., 274-275)

36 Iguman manasitra Krupa Teodosije; pop Mauk iz Otona, pop Marko Bijedov, paroh u Pađenima; protopop Jovan Novaković, paroh u Kninskom Polju; pop Avram Simić, paroh u Kosovu (Orlić); pop Krička, paroh drniški; jeromonah Spiridon Torbica iz manastira Dragović; pop Lazar; protosinđel Melentije; stari kapetan Rašković iz Golubića; Trifun Sinobad iz Knina; Simo Stefanović iz Knina; Aćim Žarković i Marko Paraskeva, trgovci iz Skradina; kapetan Jovo Grbljanin; slijepi guslar Marko; Grci Danil Moraitski i Leonardo Vordon i drugi.

37 Riječ je o Antoniju Trevisanu, rođenom Venecijancu, koji je upravljao Skradinskom biskupijom od 1767. do 1799. godine.

38 „Ti pamtiš dobro moje prebivanije u celoj Dalmaciji, gdi sam ja s amvona propovjedi govorio, ne samo po seli i po manastiri, nego i po prvi gradovi, kako u Zadru celu godinu. Ovde su me dolazili slušati poglaviti učeni od Talijanaca. 
duhovne klime nepovjerenja i zatvorenosti, karakteristične za diskriminiranu srpskopravoslavnu manjinu u Mletačkoj Dalmaciji, a i šire.

Ukoliko se i ne složimo s tom tezom, ostaje i dalje otvoreno pitanje njegove interkulturne komunikacije u Dalmaciji, posebice problematika možebitne recepcije dalmatinskih (franjevačkih) književnojezičnih zasada. U literaturi o tome postoje suprotstavljena mišljenja. Naime svjedočenje Sime Milutinovića Sarajlije iz 1839. godine otvorit će kasnije u stručnoj javnosti veliku polemiku jesu li djela slavonskih i dalmatinskih katoličkih pisaca iz XVIII. stoljeća nadahnula i Dositeja da u Dalmaciji počne pisati „prostonarodnim jezikom“.39 Dok je primjerice Jovan Skerlić Milutinovićevo svjedočanstvo smatrao vjerodostojnim i vrijednim pažnje, Mita Kostić je zastupao suprotno mišljenje, ističući da dalmatinski pisci „pouzdano nisu utjecali na novu srpsku literaturu“ “40 Kako bilo, činjenica je da se u katoličkoj (franjevačkoj) kulturi morlačke Dalmacije u XVIII. stoljeću zapaža jaka tendencija okretanja narodnom izvoru, koja će se očitovati i u Dositeja tijekom boravka u toj pokrajini. To je književnojezično usmjerenje vrhunac dosegnulo u Kačićevoj pjesmarici. Njegov Razgovor ugodni narodna slovinskog zbog „svemorlačkog“ karaktera i relativne tolerancije prema pravoslavnoj sastavnici „slovinstva“, našao je čitalačku publiku i u srpskopravoslavnoj morlačkoj sredini, a objavljen je samo pet godina prije nego što je Dositej stigao u Dalmaciju. ${ }^{41}$ Imajući u vidu navedeno, može se bez pretjerivanja konstatirati da su mladom, znanja željnom kaluđeru Dositeju poticaji dolazili s različitih strana: iz pravoslavne crkve, ${ }^{42}$ od srpske obrazovane elite, iz katoličkih književnojezičnih krugova u Dalmaciji i Slavoniji, kao i iz analfabetske morlačke sredine. ${ }^{43}$ Naime određenu ulogu svakako je mo-

Znaš kako je drago bilo našim Srbljem oficirom i pročim građanom čujući da me latinski predikatori hvale. A sad, veruj mi, stidim se za neka ondašnja govorenja. A zašto to? Eda li sam zakon moj i veru izmenio? Nisam, niti ću dok sam god živ. No naučio sam bolje i razumnije svrh mojega zakona i vere misliti i suditi." (D. OBRADOVIĆ, Sabrana dela., 319-320)

39 Sima Milutinović Sarajlija prvi je, navodno prema kazivanju samog Dositeja, upozorio da Jelena Simić, kći kosovskog prote Avrama Simića, nije bila jedina koja ga je potaknula na pisanje narodnim jezikom, već da su poticaji dolazili i iz „katoličkog susjedstva“. O tome Milutinović svjedoči: „Blažene pameti starac Dositije nije se stidio priznavati kadčto i pred svimi i u družeskom razgovoru, da je on čitavši 'Satira' Reljkovićeva, i po Dalmaciji Kačića pjesmaricu i 'Aždahu sedmoglavu' i proč. pomišljati ustao i prenuo se i sam o svojima prvom zgodom i prilikom, slovenskim slovima, barem, ka i oni latinskima, svoji isti prostonarodni jezik pisati u knjige, koje bude nedge spisavao. [...] Ova iskrenost istoga blaženoga starca primerna je i čestita je i prilična u njegovoj ozbiljnoj znanosti i uzvišenosti [...].” (Otziv na poziv 1839. god., Pešta 1839., 31.; usp. K. MILUTINOVIĆ, Vojvodina i Dalmacija 1760-1914., 5-6.).

40 „Uzroka i primera da narodnim jezikom piše imao je, dakle, Dositej dosta, ali povod da to počne dala mu je u Dalmaciji popovska kći Jelena Simićeva [...]. Prema tome, mora se više verovati samoj Dositejevoj štampanoj reči nego Siminoj tvrdnji o Dositjejevoj pričanoj reči." (M. KOSTIĆ, Dositej Obradović u istorijskoj perspektivi XVIII. i XIX. veka., 33).

41 O mogućem utjecaju Kačićeva djela na srpskopravoslavnu sredinu u Dalmaciji, i to u političkoj dimenziji, Zrinka Blažević primjećuje: „S druge pak strane, postoje indicije da je emancipacijski potencijal Kačićeva ilirizma utjecao i na porast samosvijesti pravoslavnih dalmatinskih 'Slovinjana'. To bi se moglo zaključiti prema sadržaju i tonu konfesionalno-političkih zahtjeva 'slaveno-srpskog naroda grčkoga zakona', čiji su svjetovni i crkveni predstavnici, usprkos proklamirano prolatinskoj politici aktualnog dužda Alvisa Contarinija (1757.-1759.), obraćaju 1759. mletačkom Senatu s molbom da im se odobri episkop njihova obreda služeći se pritom argumentacijom očito inspririranom Kačićevim djelima.“ (Zrinka, BLAŽEVIĆ, „Ilirski ideologem u djelima Andrije Kačića Miošića.“ Fra Andrija Kačić Miošić i kultura njegova doba, (ur. Dunja Fališevac), Zagreb 2007., 274). Pravoslavcima je Kačićevo djelo moglo imponirati i po istaknutom simboličkom statusu koji je sv. Sava imao u njegovim pjesmama (Isto, 270).

42 To se posebice odnosi na temišvarskog vladiku Georgija Popovića, koji se zalagao za reformu unutar crkve, te igumana hopovskog Todora Milutinovića, za koga Stojan Novaković kaže da je bio „prost čovek, ali racionalista po svome prirodnom zdravom razumu“ (Stojan NOVAKOVIĆ, „Dositej Obradović i srpska kultura.“, 21).

43 Tom nizu treba svakako pridodati i poticaje koje je Dositej od 1766. do 1768. dobivao u školi Jeroteja Dendrina u Smirni, „novoga grečeskoga Sokrata“. U tom smislu Milorad Ekmečić ističe: „Ipak, ni njegov jezik (Dositeja Obradovića, op. a.) nije bio sasvim jasan običnom čitaocu jer je imao puno ostataka staroslovenskog u sebi. Istraživači njegovog dela nisu postavili pitanje koliko je u ovome on bio veran sledbenik svog grčkog učitelja Koraisa, koji je ispovedao da se jezik stare crkvene književnosti mora uzeti za osnovu i obogaćivati narodnim govorom („katarevus“).“ (Milorad EKMEČIĆ, Stvaranje Jugoslavije 1790-1918. 1. Beograd 1989., 53). 
rao imati i faktor bogate usmene epske kulture dalmatinskih Morlaka, koja je izražajnom novoštokavskom ijekavštinom, tim „književnim jezikom“ narodne epske poezije, Dositeju na specifičan način imponirala. ${ }^{44}$ On će tako u Dalmaciji početi bilježiti narodne izreke, a u svojim djelima često spominje i slijepog dalmatinskog guslara Marka, od kojeg je mogao čuti mnoge narodne pjesme..$^{45} \mathrm{U}$ svoj osobit i ne uvijek „čist" narodni jezik, uključit će i dosta ijekavskih oblika, u skladu s osobinama sjevernodalmatinskih govora, inspirirajući nadolazeće naraštaje u borbi za narodni jezik (štokavštinu) kao mogući model književnojezičnog standarda. ${ }^{46}$

Zreli Dositej nastupa 1782/83, to jest nakon školovanja u Ugarskoj i Njemačkoj, kada počinje javno djelovati kao racionalistički filozof i prosvjetiteljski reformator. ${ }^{47} \mathrm{Pismo} \mathrm{Ha}$ ralampiju iz 1783. godine, ujedno i prvi tiskani Dositejev tekst, odmah je shvaćeno kao „prosvjetiteljski manifest“ koji programski najavljuje, riječima Jovana Skerlića, „duhovno oslobođenje srpskog naroda od srednjeg vijeka i Istoka i uvođenje u moderno doba i u Zapad“ ${ }^{48}$ Neka recentna književnopovijesna istraživanja međutim poriču manifestni karakter Pisma Haralampiju te ga tumače kao oblik uobičajenog prosvjetiteljskog predgovora iskazanog u formi poetičke proze s naglašenom obrazovnom ulogom..$^{49}$ Ostavljajući po strani

44 Skerlić je u više navrata naglašavao značaj Dositejeva boravka u Dalmaciji, ističući pritom i važnost sredine u kojoj je djelovao: „Tu, živeći u čistoj narodnoj sredini, imao je prilike da izbliza pozna narod, prouči sve njegove potrebe, izmeri sve zlo koje dolazi od neznanja i bede. Tu je, učeći decu, počeo pisati bukvice, ižicu, histoitiju, i to sve na narodnom jeziku, i to na jeziku jednog kraja gde se vrlo lepo i čisto srpski govori. U malome, njegova književna delatnost počinje od bavljenja u Dalmaciji.“" (Jovan SKERLIĆ, Istorija srpske književnosti u XVIII. veku., 289).

45 Dositejev odnos prema usmenoj epskoj poeziji bio je u najmanju ruku složen; negativno je ocrtavao stereotipnost te motive nasilja („krvoprolitija“) i bančenja u narodnim junačkim pjesmama, ali je ponekad u njima pronalazio i veće vrijednosti, ističući njihovu moralnu poruku i pouku. O Dositejevom odnosu prema narodnoj poeziji više pogledati u: J. DERETIĆ, Dositej i njegovo doba., 26-32.

46 Dositej je poput drugih prosvjetitelja XVIII. stoljeća u narodnom jeziku vidio najprikladnije sredstvo za prosvjećivanje puka (,jezik ima svoju cenu od polze koju uzrokuje“). Njegov jezik, koji je bio specifična mješavina „graždanskog“" (slavenosrpski) i „prostonarodnog“, nije slijedio stav o „tri stila i dva jezika“ srpskih klasicista. Pavle Ivić u tom smislu zaključuje:„Dositej je prvi značajniji srpski književnik koji je pisao isključivo narodnim jezikom. Njegovom delatnošću započinje pobedonosno nastupanje tog jezika koje će se u Vukovo vreme završiti potpunom pobedom.“ (P. IVIĆ, Pregled istorije srpskog jezika., 141). O Dositejevu jeziku i refleksu staroslavenskog ,jata“ u njegovim djelima najviše je pisala Herta KUNA u spomenutoj opsežnoj knjizi Jezičke karakteristike književnih djela Dositeja Obradovića iz 1970 .

47 Već je Stojan Novaković upozorio na činjenicu da je Dositej očito promišljeno odabrao trenutak kad će javno istupiti kao prosvjetiteljski reformator i objaviti svoja prva djela pisana u tom duhu, vezujući ga uz jozefinske ideje i reforme, nadasve crkveno-političke mjere iz 1781 - Patent o toleranciji te odredbe o ukidanju crkvenih beneficija i kontemplativnih redova: „Veza među Josifovskim pokretom i Dositejevim stupanjem u srpsku književnost vidi se iz prvih vrsta, koje su od Dositeja sveta ugledale, iz Pisma Haralampiju, koje je štampano u proleće 1783. godine. U prvim vrstama toga pisma Dositej peva čitavu pesmu caru Josifu II, nabraja u njoj njegove reforme i uzvišuje ih do nebesa. [...] Naslanjajući se očevidno na reformni pokret cara Josipa II, i ako je time vršio svoje davnašnje želje i uverenja, Dositej je odmah u lakoj, gotovo belestrističnoj formi istavio gotov plan, u koje su osnovi nove srpske prosvete, one koja se, u to vremem, sa svih strana želela.“ (Stojan NOVAKOVIĆ, „Dositej Obradović i srpska kultura“, 16-17).

48 „Dositej je“, piše Jovan Skerlić, „inicijator kulturnog i naprednog zapadnjaštva, vođa u duhovnom oslobođenju srpskog naroda od Srednjeg Veka i Istoka i u uvođenju u moderno doba i u Zapad“ (J. SKERLIĆ, Istorija srpske književnosti u XVIII. veku., 305).

49 Marija D. Stefanović tako ističe: „Interesantan je primer Dositejevog Pisma Haralampiju, koje je u nauci razumevano kao prosvetiteljski manifest ili privatno pismo s molbom za pretplatu, ili tek kao puki adligat uz Život i priključenija, koje li kobne naučne greške!, a nikad nije čitano u ključu dela koje najavljuje i čiji sadržaj opisuje; poređenjem iskaza u esejima koje najavljuje sa onima u Pismu, tako je lako, jednostavno, naučno bezbolno i bez trzavica, s velikom mogućnošću pretpostaviti kako je to bio planirani predgovor uz Sovete, pogotovo što je štampan kurzivom i bez paginacije, označavajući stranice samo zvezdicama (uobičajeno za predgovore u XVIII. stoleću). Zanimljivost takvoj poetičkoj priči daju i autobiografski elementi iskazani u predgovoru, a direktan način obraćanja pojedinačnom čitaocu uobičajenom retoričkom formulom, u vidu toposa pozdravljanja, daje im prisnost književne reči, što se lakše poučno prihvatalo. Takvu paradigmu naglašene obrazovne uloge imaju i prosvetiteljski predgovori Vida Došena, Matije Antuna Relkovića, Andrije Kačića Miošića, što ukazuje na istu kulturnu klimu i isti sloj čitalačke publike unutar Vojne granice." (Mirjana D. STEFANOVIĆ, Marijana D. Leksikon srpskog prosvetiteljstva., 172-173). 
književnopovijesne dvojbe, u našoj se historiografskoj raspravi podrazumijeva da tadašnji Dositejevi stavovi o Dalmaciji i Morlacima proizlaze iz filozofije europskog prosvjetiteljstva i terezijansko-jozefinskih reformi, ali $s$ još ponekim tragovima pravoslavne skolastike. ${ }^{50}$ Usvajajući prosvjetiteljsku etiku koja je ključna za konstrukciju drugosti, uvjetovanu dihotomijama nazadan - napredan, amoralan - moralan, surovost - plemenitost (ali ne i civilizacija - divljaštvo), i prosvjetiteljski stav da narodni jezik treba biti i književni jezik te racionalističku filozofsku misao prema kojoj je nacija „prirodna cjelina“ koju čini zajednica jezika i porijekla, Dositej je naknadno u znatnoj mjeri reinterpretirao i preformulirao svoja dalmatinska iskustva iz 1760 -ih i s početka $1770-i h .{ }^{51}$ Višeslojnost njegovih novih („prerađenih“) pogleda na Dalmaciju - koje sustavno iznosi u Životu i priključenijima i Sovjetima - ogleda se u kritici tri vrste fenomena: u kritici praznovjerja, to jest nekršćanskih vjerovanja i običaja koje je često susretao i u Dalmaciji; ${ }^{52} \mathrm{u}$ kritici religijske kulture i vjerske nesnošljivosti unutar crkvenih krugova (nadasve u kritici monaštva te crkvenih praznika i postova) ${ }^{53}$ i konačno, u kritici uloge koju običaji imaju u formiranju individualnog ponašanja i kulture uopće. ${ }^{54}$ Naime u cjelokupnom Dositejevu opusu razum i običaji nepomirljive su suprotnosti. ${ }^{55}$ Razum je za Dositeja bio element prirodnoga u čovjeku, dok je običaj element kulturnog naslijeđa. To je, kako tvrdi kulturni antropolog Ivan Kovačević, „dubinska struktura Dositejeva shvaćanja čovjeka“. ${ }^{56}$ To je, mogli bismo reći, i jedini element drugosti

50 Dositejevi stavovi o dalmatinskim Morlacima proizlaze zapravo iz strukture njegova shvaćanja običaja i tradicijske kulture općenito. Usp. I. KOVAČEVIĆ, Istorija srpske etnologije. I., 72-91.

51 Dositej na više mjesta u zrelim radovima spominje svoje prijašnje stavove iz dalmatinskog razdoblja, koje je u međuvremenu pod utjecajem prosvjetiteljskih ideja promijenio. Ogledan primjer tome je epizoda s neukim ali savjesnim i pronicljivim seoskim popom Maukom iz Otona koji je s Dositejom poveo razgovor o karakteru svećeničkog poziva: " [...] Onda sam mu ja odgovorio, po mojemu tadašnjemu načinu mišljenja, da sveštenstvo, budući dar svetoga duha i vlast duhovna, zato ko ovo ima, po tomu on je svetac. To ga je upokojilo, i ode. Sad obače ovako bih mu odgovorio: da sveštenstvo, kako god i ostala dostoinstva vojena i graždanska, neodložno iziskuje neke službe i dužnosti, koje ko ne ispolnjava, ne samo nije da se nariče svetim ocem, nego i da se liši toga dostoinstva i zvanija. A ko ih ispolnjava kako nadleži, on je pravi sveti otac i visokopočitanija dostoin, noseći popečenije o onom što je svetjejše u človečeskom rodu, to jest blagonaravije, vseopšta ljubov, mir, neporočnost i čistota sovjesti.“ (D. OBRADOVIĆ, Sabrana dela., 643-644).

52 „Ima sad više od dvanaest stotina godina od kada su Srblji Davora i Kolede za svoje bogove imali; pak i današnji dan čućeš od Dalmacije do Banata u usti gdikoje stare bake: 'Aj Davore, mili bogo!' A da je zapitaš ko je i šta je taj Davor, nikada do veke neće ti znati kazati.“" (D. OBRADOVIĆ, Sabrana dela., 315).

53 „Zašto, kako se što počne protiv starih plesnivih i zarđatih običaja činiti, namah viču: Propadosmo! Propade pravoslavje! Hoće li pravoslavje posrnuti ako narod ne bude drugih praznika krome nedelja, Hristovih i Bogorodičinih praznovati i u lenosti i neradeniju celu treću čast godine za toliko množestvo svetkovina gubiti? Lenost i neradnja, nije li smrtni greh, štetan i poguban telu i duši? Zašto da ne poznadu da u svetkovanju tolikih svetaca nijedna dlaka pravoslavja ne stoji? Zašto da im se ne kaže da su ove stvari izmišljene na šest i sedam stotina godina posle spasitelja Hrista i apostola?“ (Mirjana D. STEFANOVIĆ, Lekiskon srpskog prosvetiteljstva., 236).

54 „Samo prostota i glupost zadovoljava se vsegda pri starinskom ostati. Zašto je drugo Bog dao čoveku razum, rasuždenije i slobodnu volju nego da može rasuditi, raspoznati i izabrati ono što je bolje?“ (D. OBRADOVIĆ, Život i priključenija., 11).

55 Općenito se drži da je Dositej etnografsku građu, obično u vidu opisa običaja i raznih oblika usmenog stvaralaštva od poslovica do epskih pjesama, unosio u svoja djela kako bi njima ukazao na pouku („naravoučenije“). Uspoređujući etnološke aspekte dviju kulturno-povijesnih epoha, prosvjetiteljstva i romantizma, a na primjeru djelovanja Dositeja Obradovića i Vuka Karadžića, Ivan Kovačević u tom smislu naglašava: „Ukratko: Dositej je učitelj narodni, Vuk je onaj koji narod proučava. Dositeju je folklorno gradivo sredstvo za pouku, Vuku cilj naučnog istraživanja. Dositej je narodski (popularni) književnik, Vuk narodni proučavalac." (I. KOVAČEVIĆ, Istorija srpske etnologije. I., 46). Doduše, već je Tihomir Đorđević upozorio da je Dositej osim ukazivanja na negativne primjere iz „primitivne“ narodne kulture (praznovjerje, osveta, rasipanje o slavi i blagdanima, vražda, nesloga itd.) isticao i neke dobre strane tradicije i običaja: milošta na radu („moba“), gostoljubivost („stranoljubije“), osjećaj časti i poštenja i slično. (Tihomir ĐORĐEVIĆ, „Dositej Obradović i folklorno gradivo.“, 48, 49).

56 I. KOVAČEVIĆ, Istorija srpske etnologije. I., 89. 
kad je u pitanju Dositejev odnos prema dalmatinskim Morlacima koji su snažno privrženi (da ne kažemo da robuju) običajima i praznovjerju.

Stigavši u Dalmaciju neposredno nakon progonstva vladike Simeona Končarevića, Dositej je lako mogao na svim razinama društvenog života osjetiti problem vjerske nesnošljivosti koji će kasnije postati jednom od njegovih glavnih preokupacija. ${ }^{57}$ Ta nesnošljivost ogledala se u sukobu nepomirljivih interesa katoličke hijerarhije u Dalmaciji, koja je težila za duhovnim monopolom i obnovom isključivih jurisdikcijskih prava nad „novom“ i „najnovijom stečevinom" (katoličkoobnoviteljski prozelitizam), i predstavnika srpske crkve, koji su, našavši se u novim okvirima katoličke države, nastojali pod svaku cijenu očuvati svoj partikularni karakter, to jest vlastito uređenje i institucionalnu autonomiju, konfesionalni identitet te duhovnu povezanost sa središtima srpskog pravoslavlja u Osmanskom Carstvu i Habsburškoj Monarhiji (pravoslavni etnofiletizam).$^{58} \mathrm{U}$ suštini, bio je to sukob dviju ranonovovjekovnih vjersko-političkih koncepcija: zapadnjačke (cuius regio eius religio), nastale tijekom vjerskih sukoba u Europi u XVI. i XVII. stoljeću, i istočnjačke (sustav milleta), koja je seobom crkve i naroda prenesena s područja Osmanskog Carstva. Ta se nepomirljiva i potpuna oprečnost iz crkvenih sfera prelijevala i u niže pučke slojeve, pa tako i u morlačku sredinu, gdje je naročito bila izražena u vidu srpskopravoslavnog, rkačkog, i rimotakoličkog, bunjevačkog, antagonizma. ${ }^{59}$ Riječ je o vjerskim podjelama i suprotnostima koje se ne mogu sasvim objasniti i razumjeti tek utjecajem crkvenih i državnih struktura, bez uvida i u određene socio-psihološke i kulturno-antropološke fenomene (npr. narcizam malih razlika, mentalne barijere i slično). Uostalom, potreba zajednica koje se nalaze u susjedstvu, i koje su i u svakom drugom smislu bliske jedna drugoj, da se međusobno razlikuju i uzajamno spore po mnogim kriterijima, pa tako i vjerskom, nije bila svojstvena samo morlačkoj sredini u Dalmaciji. Ono što je u tom kontekstu specifično, jest da su vjerske razlike oblikovale i učvršćivale etnička razgraničenja, anticipirajući moderne nacionalne srpsko-hrvatske identitete u Dalmaciji, a i šire. Na mnogim mjestima lako se može prepoznati to Dositejevo iskustvo iz sjeverne Dalmacije: u pismu svojem literarnom sugovorniku, ocu Serafimu u Sovjetima, u kojem se zgraža zbog „mrzosti na zakon“ koja vlada među kršćanima različitih provenijencija, a nastaje najčešće zbog nekih sitnih razlika u vjerskoj službi; ${ }^{60} \mathrm{u}$ Basnama gdje donosi čitav niz etnokonfesionalnih „nadimaka“ kojima su se međusobno častili pravoslavci i katolici od Dalmacije do Banata. ${ }^{61}$ Međutim izvor vjerske nesnošljivosti Dositej

57 O vjerskim prilikama u Dalmaciji i važnosti nižeg klera u životu običnog puka, koji su silom prilika djelovali izvan episkopske vlasti, Dositej je u Životu i priključenijima zabilježio: „Grečeske cerkve narod u venecijanskoj Dalmaciji, ne imajući episkopa, oni od mirskih sveštenika koji su poznati za svoje česno vladanje, za dobrodjetelj i za prirodni zdravi razum, tu su ne samo u svojim parohijam no i u celoj provinciji kako god patrijarsi i episkopi. Takovi su bili u vreme mojeg onde prebivanja. Joan Novaković kninjopoljksi, Avram Simić kosovski i Krička derniški. (D. OBRADOVIĆ, Život i priključenija., 113).

58 Otprilike u vrijeme Dositejeva boravka u Dalmaciji i na Sredozemlju ukinuta je 1766. godine Pećka patrijaršija. Inače, uoči Dositejeva dolaska u Dalmaciju, a prema izvješću koji donosi generalni providur Alviso Contarini 1758, u toj su provinciji u 52 parohijske crkve služila 44 pravoslavna svećenika s 19 đakona i klerika, a u manastirima Krki, Krupi i Dragoviću živjela su 52 kaluđera i 21 poslušnik (Rajko, VESELINOVIĆ, „Srbi u Dalmaciji.“, 37).

59 O konfesionalno suprotstavljenim grupama „Rkači“ - „Bunjevci“ unutar vlaških (morlačkih) društava u Dalmaciji, ali i na širem dinarskom etnokulturnom prostoru, pogledati u: Marko ŠARIĆ, „Bunjevci u ranome novom vijeku: postanak i razvoj jedne predmoderne etnije“, Živjeti na Krivom Putu, svezak I. (ur. Milana Černelić, Marijeta Rajković, Tihana Rubić), Zagreb 2008., 15-43.

60 „[...] koliki pošteni i čistosrdečni narod u Dalmaciji, Horvatskoj i Slavoniji, jednoga naroda i jezika, i koji u istoga Isusa spasitelja veruje, mrzi se, ukorava se, goni se i jedan drugom ljutu nepravdu čini! Zašto? Za post: ko posti sredu, on je Rkać, a ko subotu, on je Bunjevac." (D.OBRADOVIĆ, Sabrana dela., 333).

61 „Gdi se god između sebe u komšiluku mrze, to po najvećoj časti proishodi iz toga što su neki grečeskoga i neki rimskoga zakona, i nariču jedni druge s kojekakvi ružni i prezritelni imenami; prvi ftore zovu ili Šokci, ili Bunjevci ili 
vidi u crkvenim krugovima, napose u monaštvu, a ne u narodu, što ga čini bliskim Fortisu, Lovriću i drugim prosvjetiteljima. ${ }^{62}$ Zadojen idejama o vjerskoj toleranciji Josipa II, Dositej je jasno iskazao antiklerikalno stajalište, iznoseći kritiku i „grčkih“ i „latinskih“ crkvenih institucija koje su, umjesto da budu duhovna ujediniteljska veza, svojim eklezijalnim egoizmom davale glavni poticaj u uspostavljanju sustava malih, ali gotovo nepremostivih razlika među stanovništvom koje je u mnogo čemu dijelilo zajedničku tradiciju, jezik i porijeklo. ${ }^{63}$ Pri tome Dositejeva kritika nije dirala u temelje kršćanske vjere: razumna pobožnost i prosvijećena vrlina ostali su njegovi ideali. ${ }^{64}$

\section{III.}

Već je rečeno da u Dositejevim djelima nema traga konceptu „plemenitog divljaka“, niti se pojam „Morlak“ uopće koristi. Dositej nije morao „otkrivati narod u prirodnom stanju" poput Alberta Fortisa i drugih putnika iz zapadne Europe, inspiriranima djelima Rousseaua i Voltairea, kojima je to bila kulturološka potreba. Treba voditi računa da je fenomen morlakizma nastao unutar diskurzivne matrice venecijanskog prosvjetiteljstva, pa ga je sukladno tome potrebno promatrati ponajprije u kontekstu jadranske transkulturne povijesne problematike. Fortisovo „otkriće Morlaka“s venecijanske točke gledišta bilo je zapravo „nova slika Morlaka“, izraz novoga, prosvjetiteljskoga imaginacijskog konstrukta. ${ }^{65}$ Riječ je o slici Morlaka kao kulturnog Drugog u funkciji vlastite kulturne (i civilizacijske) retrospekcije, koja je imala dvije razine: prva je podrazumijevala perspektivu Venecije kao imperijalnog središta (Morlak kao prekojadranski Drugi), a druga je uključivala provincijsku perspektivu priobalne (komunalne) Dalmacije (Morlak kao dalmatinski Drugi). ${ }^{66}$

Rimci ili Latini, a ovi one: Vlasi, Rkaći i Šizmatici, a česno, sveto i bratsko ime hristjani - to svak samo za se drži, ili ako kad jedna strana drugu nazove Kršćani ili Rišćani, to se za osobitu milost i učtivost tvori i drži, i po nesreći vrlo retko biva. (Isto, 684-685).

62 Za razliku od „parazitskih“ kaluđera, Dositej je prema svjetovnom („mirskom“) svećenstvu imao više simpatija, zalažući se za njihovo kulturno uzdizanje i veću ulogu u vjerskom i kulturnom životu crkve i naroda. Taj osjećaj naklonosti jasno dolazi do izražaja i u njegovim sjećanjima na Dalmaciju: „Takovi su bili u vreme mojeg onde prebivanja: Joan Novaković kninjopoljski, Avrâm Simić kosovski i Krička derniški. Njima soveršeno priličestvuje ono slovo apostola Pavla da ko god dobro upravlja domom i familijom svojom, taj će i cerkovju, to jest s cerkovnim opštestvom blagorazumno upravljati. Bez nauke, jer je nisu imali gdi polučiti, ali (to što je važno i veliko u životu) ne samo bez nikakove zlobe no i sa svakim naravnim česnim svojstvom ukrašeni. [...] Kakovo blaženstvo i raj na zemlji s onakovim svetim i dobrim ljudima živiti! Ono su pravi sveci, a niti znadu niti misle da su." (D. OBRADOVIĆ, Život i priključenija., 113).

63 „Zato, o prečesno opštestvo človečeskoga roda, a navlastito serbskoga, za koga ja ovo pišem, poslušaj ti glas čelovečestva, sveti glas jestestva, a to će reći glas Božji! Ne razdeljujte se i ne mrzite se između sebe za crkve grčku i latinsku. Cerkov je Hristova, a niti je grčka ni latinska; nego samo gordost i inat i zloba uvela su ova imena, razdelila i omrazila tolike poštene i blaga srce ljude." (ISTI, Sabrana dela., 539).

64 S. ĆIRKOVIĆ, Srbi među evropskim narodima., 178.

65 „Intelektualno otkriće Dalmacije“ počelo je zapravo 1758. godine kada je mletački komediograf Carlo Goldoni predstavio svoju novu komediju La Dalmatina u kojoj je oslikao Dalmatince kao vjerne i sretne mletačke podanike (Josip VRANDEČIĆ, „Dalmacija i Dubrovnik u ranome novom vijeku [1420-1797].“ , Dalmacija, Dubrovnik i Istra u ranome novom vijeku (Josip VRANDEČIĆ i Miroslav BERTOŠA), Zagreb 2007., 71). Usp. Larry WOLFF, Venice and the Slavs. The Discovery of Dalmatia in the Age of Enlightenment, Stanford 2001., 25-29. O Goldonijevoj predodžbi Dalmatinca kao „dobrog vojnika“ nasuprot Gozzijeva modela „zlog i nepopravljivog divljaka“ koji je bio na tragu ranijih mletačkih negativnih percepcija morlačkog stanovništva, više pogledati u: Nino RASPUDIĆ, Jadranski (polu)orijentalizam. Prikazi Hrvata u talijanskoj književnosti. Zagreb 2010., 155-180.

66 Nino Raspudić primjećuje da u Italiji još uvijek ne postoje studije koje bi sa stanovišta postkolonijalne teorije analizirale talijanski, pa tako i venecijanski diskurs o istočnoj obali Jadrana. Isti autor, polazeći od postkolonijalne teorije Edwarda Saida i modelâ balkanskog i istočnojadranskog „poluorijentalizma“ Marije Todorove i Larryja Wolffa, pod 
Dositej nije pripadao tome prosvjetiteljskom krugu, niti je iskazivao interes za takvu vrstu književne obrade morlačkih motiva, već je usvojio i u srpsku sredinu prenosio prvenstveno njemačku varijantu prosvjetiteljstva u kojoj je, za razliku od onog talijanskog, francuskog ili engleskog, morlakizam imao najslabiji odjek. To će promijeniti tek Herderov predromantizam kada posredovanjem šire (južno)slavenske tematike i morlački motivi snažnije prodiru u srednjoeuropsku literaturu. ${ }^{67}$

Jednako tako Dositeja teško možemo povezati i s fenomenom morlakizma na način kako ga shvaća Larry Wolff - kao konstrukt venecijanskog prosvjetiteljsko-kolonijalnog diskursa, drugim riječima, kao sredstvo mletačke kulturne i političke dominacije u Dalmaciji. ${ }^{68}$ Naime taj je američki povjesničar, polazeći od postkolonijalne teorije Edwarda Saida i mletačke derivacije orijentalizma Paola Preta, povezao kulturne aspekte venecijanskog prosvjetiteljstva s imperijalnom ideologijom Serenissime, što je, prema njegovu tumačenju, u konačnici rezultiralo stvaranjem polukolonijalnog i poluorijentalnog diskursa (demi-Orientalism) koji je Metropola razvijala prema svom posljednjem važnijem prekomorskom posjedu u XVIII. stoljeću. ${ }^{69}$ Wolff zapravo korijene prosvjetiteljskog fenomena koji naziva „otkrićem Istočne Europe“ (Inventing Eastern Europe) nalazi upravo u fenomenu morlakizma, čime su Dalmacija i njeno morlačko stanovništvo postali oglednim primjerom imaginarne konstrukcije koja teži za „unutarnjom orijentalizacijom“ Europe. ${ }^{70}$ Takvoj slici divlje i pomalo tajanstvene Dalmacije na „granici svjetova“ gdje se Zapad susreće s Istokom, kakvu nam donose putopisi prosvjetiteljske epohe pridonijela je, dakako, višestoljetna situacija imperijalnog višegraničja (mletačko-osmansko-habsburškog) pri kojoj su dodir s Drugim, ali jednako tako i prožimanje, miješanje i prepletanje s Drugim, postali prepoznatljivim odlikama toga prostora, a time i pogodni za različite binarne konceptualizacije i esencijalističke konstrukcije imaginarne i simbolične geografije koja nastaje

pojmom „(polu)orijentalizam“ imenuje diskurs talijanske književnosti o Hrvatima. O tome konkretno kaže: „Teorijsko i metodološko opravdanje korištenja postkolonijalne kritike u ovom kontekstu leži u činjenici da se tijekom većeg dijela povijesti talijansko-hrvatski odnosi odvijaju kao odnosi „nadređene“ i „podređene“ kulture, a u nekim povijesnim razdobljima i kao, najprije venecijanska, a kasnije i talijanska, izravna politička, vojna i ekonomska dominacija nad dijelovima današnjeg hrvatskog teritorija. Ta asimetričnost hrvatsko-talijanskih odnosa se odražava i na uzajamne književne prikaze. Ona s jedne strane nužno ostavlja tragove na književnom tekstu, no s druge strane i taj tekst dijelom sudjeluje u njezinom proizvođenju, potvrđivanju, opravdavanju i neprestanom obnavljanju." (Isto, 6).

67 Književna obrada morlačkih motiva u njemačkoj sredini počinje s Hasanaginicom, potresnom epskom baladom što ju navodi Fortis u svom putopisu, a prevodi sâm Goethe koji je njome bio oduševljen. Hasanaginica je od samog početka pobuđivala interes u smislu novoga predromantičarskoga književnog osjećaja za autohtone arhaične kulture i genij narodnog stvaralaštva, sasvim različitog od prosvjetiteljskog ukusa. Inače je ta pjesma ogledan primjer transkulturalnosti koja se oblikovala na području imperijalne Tromeđe u ranome novom vijeku, a ujedno je i potvrda koliko je narodna (pučka) kultura na prostorima Tromeđe, za razliku od sfere visoke/elitne kulture, bila znatno više obilježena interkulturalizmom, odnosno gdje su se „kulturne granice“ lakše premošćivale i nisu podlijegale strogim ograničenjima. Naime po svome postanku, značajkama i općoj atmosferi Hasanaginica je podjednako i „turska“ i „morlačka“ pjesma, dalmatinska i bosansko-hercegovačka; hrvatska, srpska i bošnjačka. Sam Fortis nije naveo kako je došao do teksta pjesme i tko je bio eventualni kazivač. Proučavajući Fortisovu korespondenciju, Žarko Muljačić iznosi pretpostavku prema kojoj je pjesmu saopćila stanovita djevojka Stana iz sela Drvenjaka na obroncima Svilaje kod Drniša, koja je Fortisu vodila domaćinstvo u raznim mjestima Italije, možda već od 1771, a sasvim sigurno od 1773. godine (Źarko MULJAČIĆ, Fortisološke studije, Split 2011., 76-86.).

68 Larry Wolff u tom smislu Fortisov intelektualni angažman u Dalmaciji smatra neodvojivim od mletačkoga imperijalnog konteksta (L. WOLFF, Venice and the Slavs., 158, 319-324).

69 Isto, 17, 319-331.

70 Prema Wolffu, Fortisovo djelo nije bilo samo ključno za formiranje intelektualnoga orijentalističkog diskursa o istočnoj obali Jadrana i njegovu slavenskom stanovništvu, već i za Istočnu Europu u cijelosti, prikazujući ih kao prostore medijacije civilizacije i barbarstva (Zapada i Orijenta), odnosno prostore „unutarnje drugosti“ Europe (Isto, 203-204., 324-328.). Usp. L. WOLFF, Inventing Eastern Europe: The Map of Civilization on the Mind of the Enlightenment, Stanford 1994. 
u XVIII. stoljeću. ${ }^{71}$ Smještati Dositeja u takvu asimetriju pojmova Istok - Zapad krajnje je nezahvalno jer on pripada objema stranama te svojim porijeklom, životom i uvjerenjem takvu vrstu dihotomije relativizira. U svakom slučaju, Dositeju se u odnosu spram Morlaka ne može pripisati osjećaj kulturne nadmoći koji se krije u pozadini svakog orijentalističkog diskursa, pa tako i spomenutog "prekojadranskog" u Wolffovu smislu riječi. Njegova kritika nekih morlačkih običaja (npr. praznovjerja) ne proizlazi iz nadmoćne pozicije kulturne drugosti, već iz pokušaja da reformira kulturnu sredinu kojoj i sam pripada.

Stekavši višegodišnje iskustvo života u morlačkom podneblju, Dositej je dobro upoznao njihov oskudan i težak život, bogato narodno stvaralaštvo, narječje i običaje - plemenitu jednostavnost njihove dinarske kulture. ${ }^{72}$ To iskustvo „iz prve ruke“ utjecalo je i na njegovu stereotipizaciju Morlaka i njihova kraja. U njegovim očima oni nisu dobri i plemeniti divljaci, već dobri i plemeniti priprosti ljudi i još k tome sunarodnjaci, koje želi podučiti u prosvjetiteljskom duhu. ${ }^{73}$ Dok u tom kontekstu primjerice padovanski prirodoslovac Alberto Fortis i francuski liječnik i botaničar u habsburškoj službi Balthazar Hacquet nastupaju kao „autsajderi“, splitski liječnik i dalmatinski iluminat Julije Bajamonti kao „unutrašnji autsajder“, a domaći Ivan Lovrić kao „vanjski insajder“, Dositej je „stranac koji to nije“. U Mletačku Dalmaciju dolazi, doduše, kao habsburški podanik, to jest kao politički stranac ili prišelac (došljak) kako sam kaže, a s obzirom na njegovo banatsko (južnougarsko), varoško porijeklo, stranac je bio i u određenom sociokulturnom smislu. ${ }^{74}$ Međutim zajednička konfesionalno-kulturna veza s lokalnim „grečeske cerkve narodom“ te zajednički jezik i njemu toliko draga gostoljubivost dalmatinskog puka u cjelini djeluju tako da ne doživljava Dalmaciju i njeno stanovništvo kao drugost (,i samo ime Dalmacija poljubi

71 Analizirajući položaj Dalmacije u svjetlu tzv. „filozofske geografije“, u kojoj prosvjetitelji spoznaju zaostalog dijela Europe podređuju filozofskim vrijednostima zapadne Civilizacije, Alen Tafra zaključuje: „Konačno, moguće je s puno prava tvrditi kako šire područje Dalmacije predstavlja privilegirano područje za imagološku analizu razvoja eurocentričnog diskursa, a osobito tijekom posljednja tri stoljeća. To su, uostalom, stoljeća kada sve bitne sastavnice narečenog diskursa okoštavaju u efikasan stav, a upravo tada Dalmacija predstavlja prostor triplex confinium-a na kojemu se latinski Zapad neposredno dodiruje s Istokom, gdje je potonji među sobom podijeljen na grčko-pravoslavni i onaj islamsko-orijentalni. Ujedno, riječ je o Slavenima koji podjednako kompliciraju metageografijsku konstrukciju Srednje Europe, Balkana, Istočne Europe, konačno, i Mediterana. Utoliko se na našem terenu kategorije poput orijentalizma, balkanizma, mitteleuropejstva, okcidentalizma i mediteranizma predstavljaju podjednako nesavršene pokušaje teorijskog i kritičkog posredovanja između ideološkog esencijalizma i hibirdne stvarnosti.“ (Alen TAFRA, „Dodir Mediterana i Istočne Europe u svjetlu 'filozofske geografije'.“, Metodički ogledi, 18-1/2011., 75.).

72 „Iz Venecije pređem s Danilom, drugom mojim, u Zadar, prvi i poglaviti grad u Dalmaciji. Meni je poznato bilo da ovde ima dovoljno Serbov oficira i trgovaca i da sam se s kojim god od njih poznavao, može biti da bi me tu zadržali. Ali ja, prirodno strašiv i stidljiv, nikada nisam mogao sebe preopručivati i u poznanstvo drugih utiskivati se i nametati. Zato ti ja pohitim u ona moja blažena sela i polja gdi sam ja već dobro poznat i gdi, bez najmanjih ni s jedne ni s druge strane ceremonisanja, komplimentiranja i u milost preoporučivanja, jedva ćemo se dočekati." (D. OBRADOVIĆ, Život i priključenija., 144).

73 Čitava Dositejeva djelatnost bila je usmjerena na to kako srpski narod „izbaviti i osloboditi od tiranstva, gluposti i varvarstva“ i kako „svet razuma čak do prostih pastirskih koliba raširiti“. Oduševljenje i neograničeno povjerenje u moć znanosti i obrazovanja najširih masa, te budućnost prosvijećene nacije, Dositej posebno iskazuje u jednom naravoučeniju u „Basnama“: „Slavna slavenoserbska nacijo u Serbiji, Bosni, Dalmaciji sa Hercegovinom, um kad s naukom prosvetiš i s prosveštenoju dobrodjeteljiju sojediniš, izabranije nacije nad tobom neće biti na zemlji.“ (ISTI, Sabrana dela., 551).

74 Dositej je zapravo i po majci i po očevim precima bio seljačkog porijekla, tako da mu seoski ambijent nije bio sasvim stran („Ostaj mi zbogom, o predrago selo, mesto roždenija roditeljnice moje!“). Moguće je da se već u rodnom Banatu, ili nešto kasnije u Srijemu, prvi put susreo s ljudima dinarskog podneblja, Dalmatincima-mletačkim prebjezima i Ličanima, koji su u sklopu vojnokrajiške kolonizacijske politike u XVIII. stoljeću naseljavani u te krajeve. Uostalom, duhovne veze i protok ljudi i informacija između srpskopravoslavnih manastira, usprkos političkim granicama, uvijek su bili intenzivni i svakodnevni. Dositej tako spominje stanovitog proigumana Makarija iz manastira Dragović, koji je „nekoliko redi svu Mađarsku obigrao“ skupljajući milodare. (D.OBRADOVIĆ, Sabrana dela., 549). 
mi se“). ${ }^{75}$ Dapače, prema njegovu viđenju, iznesenom 1783. godine, „žitelji dalmatiski“

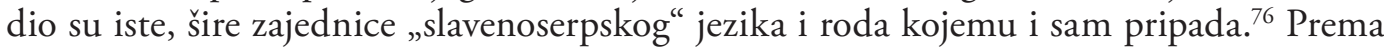
tome, dalmatinski Morlaci oba vjerozakona samo su „čest“ veće narodnosne cjeline koja je prelazila granice političke, privilegijalne ili konfesionalne zajednice. ${ }^{77}$ Ipak, valja primijetiti da Dositej na srpski narod gleda kao na složenu (heterogenu) cjelinu, očito uvažavajući historijsko-geografske i socio-kulturne posebnosti jednoga policentričnog prostora, „od Adrijatičeskoga mora do reke Dunava“. Tako primjerice ponekad koristi i pluralni oblik, govoreći o „svim slavenosrpskim narodima“ ${ }^{78}$

Dositej tako u Životu i priključenijima otvara povijest moderne srpske kulture, odražavajući svu složenost njezina naslijeđa i najavljujući ujedno njezine suprotnosti, proturječja i iluzije. Kao pronicljiv promatrač svoga vremena i društva profilirao se u „glasnika" ne samo građanske misli - iznoseći kritiku crkvene kao i dijela pučke tradicije - već i modernog određenja srpske nacije, temeljenog na jezičnom (štokavskom) i sekularnom (transkonfesionalnom) načelu. ${ }^{79}$ Doduše, i dalje je otvoreno pitanje koji su sve konkretni izvori vodili Dositeja prema artikulaciji srpske nacije kao zajednice koja živi u granicama štokavskog narječja, u kojoj je to mjeri bilo njegovo znanje pisane riječi i bogate erudicije, odnosno teorijske naobrazbe (ex libris), ${ }^{80}$ a u kojoj mjeri njegovo iskustvo promatranja i iznimne po-

\footnotetext{
5 ISTI, Život i priključenija., 112 .
}

76 „Ja sam različne nacije želio i iskao poznati, a navlastito našu slavenoserpsku od Banata do Albanije. U Serbiji, u Bosni, u Slavoniji, u Dalmaciji i Hercegovini, svuda je u seljani ovi kraljevstva harakter voopšte jednak, kao da su, kako i jesu, jedna familija." (ISTI, Sabrana dela., 684).

77 Dositej već u „Pismu Haralampiju“ na više mjesta jasno iznosi svoju koncepciju srpske nacije koja je nadilazila vjerske, državne i pokrajinske podjele: „(...) kaži mu da što je god Srbalja, od Adrijatičeskoga mora do reke Dunava, svi će ga pohvaliti“ (ISTI Život i priključenija., 10); „Ko ne zna da žitelji črnogorski, dalmatski, hercegovski, bosanski, servijski, horvatski (kromje muža), slavonijski, sremski, bački i banatski (osim Vlaha) jednim istim jezikom govore? Govoreći za narode koji u ovim kraljevstvam i provincijam živu, razumevam koliko grčke crkve, toliko i latinske sljedovatelje, ne isključavajući ni same Turke Bošnjake i Hercegovce, budući da zakon i vera može se promeniti, a rod i jezik nikada.“ (Isto, 11); „Zato, dakle, ja ću pisati za um, za srce i za naravi človečeske, za braću Srblje, kojega su god oni zakona i vere.“ (Isto, 13); „Tebi dakle, o ljubeznjejši i slačajši slavenosrpski narode, posveštavam koliko ovu toliko i one koje će sledovati plode i žertve mojega pera. Vami, poželani žitelji Serbije, Bosne, Hercegovine, Črne Gore, Dalmacije, Horvatske, Srema, Banata i Bačke, vami i vašim poslednjim unukom, s gorećim i punim ljubavi srcem, ovi moj mali no usredni trud predajem!“ (Isto, 24).

78 „A najpače, poznavajući mužestveni harakter i pošteno srce sviju slavenoserpskih naroda od Črne Gore do Banata, uzdam se da ćedu s ljuboviju primiti moja predstavljenija." (D. OBRADOVIĆ, Život i priključenija., 100).

79 Prema Jovanu Skerliću, Dositej Obradović je 1793. godine prvi upotrijebio i riječ „nacionalist“ u modernom političkom značenju, kako ga tumači racionalistička filozofija i ideologija liberalnog građanstva (J. SKERLIĆ, Istorijski pregled srpske štampe 1791-1911. Sabrana dela VIII, Beograd 1960., 66.). Milorad Pavić pak ističe da je termin „nacionalist" prvi uveo Zaharija Orfelin. (M. PAVIĆ, Istorija srpske književnosti klasicizma i predromantizma. Klasicizam, Beograd 1979., 78).

80 Još je 1765. povjesničar Pavle Julinac u svojoj knjizi Kratkoje vvedenije v istoriju proizhoždenija sloveno-serbskago naroda iznio racionalističku definiciju srpske nacije kao zajednice jezika koja je potekla od „sibirskih“ Slavena. O jačanju srpske narodnosne (i jezične) samosvijesti u novim političkim i kulturnim kontekstima druge polovice XVIII. stoljeća, svjedoče i djela Jovana Rajića, Zaharije Orfelina i Stefana Novakovića. Dositejevim tvrdnjama iz 1783. godine vremenski koincidiraju jezikoslovne rasprave „Oca slavistike“ Josefa Dobrovskog iz 1782. i 1788. u kojima je „neodređeno“ ilirsko ime, koje se u literaturi XVIII. stoljeća najvećma odnosilo na štokavske zajednice svih triju vjera u Habsburškoj Monarhiji i Osmanskom Carstvu, poistovjetio sa srpskim, čime je položio temelj kontroverznoj teoriji o srpskom karakteru štokavštine. Može se s razlogom pretpostaviti da je političkoj sekularizaciji srpstva i izlasku srpskog imena iz etnokonfesionalnih okvira krajem XVIII. stoljeća, možda najviše pridonijela habsburška prosvjetiteljskoapsolutistička politika. Treba se samo sjetiti koliko je „austrijska“ država svojom reformom škola utjecala na razvoj srpskog jezičnog (građanskog) idioma, što je također bio odmak od stare tradicije. Habsburška je država na temelju „srpskih privilegija“ s kraja XVII. stoljeća, od 1745. konstituirala i „ilirsku naciju“ kao zaseban politički narod, izuzet od ugarskog (i hrvatskog) političkog naroda. Ilirsko ime, doduše, nikada neće zaživjeti među Srbima, ali ta je epizoda također mogla pridonijeti političkoj sekularizaciji srpstva u Monarhiji, koja je do punog izražaja došla 1790. godine na Temišvarskom saboru, na kojem se već jasno razlučuje pripadnost vjerozakonu od pripadnosti narodu. 
kretljivosti (ex nautra) ${ }^{81}$ Povijesna znanost dakle tek treba utvrditi okolnosti pod kojima se u pojedinih erudita XVIII. stoljeća, pa tako i u Dositeja, prostor postulirane „ilirske“ zajednice izjednačuje sa srpskim (,slavenosrpskim“) imenom koje je do tada, nota bene, imalo uže povijesne konotacije. ${ }^{82}$ Dositejev je „panserbizam“, doduše, kako to slikovito kaže Milorad Ekmečić, „dirnuo u osinjak “ nacionalnointegrativne problematike na južnoslavenskom prostoru, ${ }^{83}$ ali je isto tako već vrlo rano prepoznato da je ta koncepcija imala i svoj drugi aspekt, koji ga je vezivao $s$ jednim drugim integracijskim programom - južnoslavenskim. Dositej je naime, pledirajući neumorno za vjersku snošljivost i narodni jezik, pridonosio prevladavanju religijskih, kulturnih i povijesnih podjela i nepovjerenja na južnoslavenskom (,ilirskom“) prostoru te međusobnom otvaranju i razumijevanju različitih konfesionalnih zajednica i kulturnih tradicija, a što je djelovalo anticipacijski i u pogledu razvoja ideja o južnoslavenskoj bliskosti i uzajamnosti. ${ }^{84}$ Stoga ne treba čuditi da je Dositej snažno utjecao ne samo na krug (veliko)srpskih nacionalnih pregalaca u političkom i kulturnom životu Srbije i Južne Ugarske (Vojvodine) XIX. stoljeća već jednako tako i na hrvatske ilirce koji su u njemu gledali jednog od preteča ilirizma, „slavnog ilirskog Anaharsisa“, odnosno „ilirskog Sokrata", kako ga se često atributiralo u Gajevoj Danici. ${ }^{85}$

Budući da Dositej u dalmatinskim Morlacima gleda sunarodnjake, njemu bliske ljude, teško da bi se išta u njegovim „opisanijama“ moglo podvesti pod morlakizam. Pa ipak „Dositejev morlakizam“ je osebujan. Ono što ga najviše veže za morlakistički diskurs jest umjerena idealizacija stanovnika dalmatinske unutrašnjosti: to su pravdoljubivi i pošteni ljudi, ali ih neprosvijećenost i praznovjerje čine zaostalima i u duhovnim i u svjetovnim

81 Već je Jovan Skerlić upozorio na brojna Dositejeva putovanja i život u mnogim srpskim krajevima koji su kod njega stvorili „osećanje velike narodne zajednice“ (J. SKERLIĆ, Srpska književnost u XVIII. veku., 341). Na prostornu pokretljivost kao čimbenik nacionalnog osvješćivanja srpstva u drugoj polovici XVIII. stoljeća upozorava i Drago Roksandić: „Kada se ima u vidu razmjerno velika pokretljivost pravoslavnoga svećenstva, sve brojnijeg učiteljstva (kao socijalnostatusno marginalnog sloja u samoj srpskoj etničkoj zajednici, čiji se pripadnici učestalo sele od mjesta do mjesta) razumljiva je rana 'zrelost', prije svega u nacionalnoideologijskom smislu, procesa srpske nacionalne integracije posvuda, pa i u hrvatskim zemljama, koja jasno dolazi do izražaja na Temišvarskom saboru 1790. godine." (Drago ROKSANDIĆ, Srbi u Hrvatskoj od 15. stoljeća do naših dana, Zagreb 1991., 66).

82 Na tragu stavova Dositeja Obradovića i Josefa Dobrovskog bio je tada i Vikentije Ljuština (rođen 1761. u Metku u Lici), koji je u Beču 1794. godine objavio Gramatiku italijansku. Ljuština u predgovoru napominje da ne namjerava okrnjiti ugled crkvenoslavenskog jezika time što je njegova talijanska gramatika „spisana opštim narečijem iliričeskim, obiknoveno slavenoserbskim nazvatim.“ M. PAVIĆ, „Književni tokovi srpskog predromantizma“ (http://www. rastko.org.yu/knjizevnost/pavic/predromantizam/mpavic-predromantizam-1html), 16. 10. 2004.

83 M. EKMEČIĆ, Stvaranje Jugoslavije 1790.-1918., 53.

84 Ferdo Šišić naziva Dositeja „prvim evangelistom ideje južnoslavenskog narodnog jedinstva“, pozivajući se pritom na Jovana Skerlića i njegovu ocjenu prema kojoj je Dositej prvi formulirao ideju narodnog jedinstva bez obzira na vjersku podjelu, uzdižući nacionalizam nad konfesionalnim shvaćanjem. (Ferdo ŠIŠIĆ, Južnoslovenska misao. Istorija ideje jugoslovenskog narodnog ujedinjena i oslobođenja od 1790-1918., Beograd 1937., 11-12.).

85 O Dositeju kao jednom od preteča ilirizma i promicatelju ideje o kulturnom i narodnom jedinstvu Južnih Slavena mislio je, među ostalima, i vođa ilirskog pokreta Ljudevit Gaj. To stajalište dijelili su i drugi njegovi suradnici, poput primjerice njegova emisara u Beogradu Pavla Čavlovića, urednika lista Branislav. Usp. Josip HORVAT. Ljudevit Gaj. Njegov život, njegovo doba, Zagreb 1970., 111; Jaroslav ŠIDAK, Hrvatski narodni preporod. Ilirski pokret, Zagreb 1990., 149-151; ISTI, „O uredniku i značenju ilirskog Branislava (1844-45).“, Historijski zbornik, XIV/1961., 75-87. O utjecaju Dositejeva opusa u artikuliranju ideologije ilirizma Drago Roksandić u kratkom eseju, jednom od rijetkih problemskih osvrta na temu Dositeja i srpsko-hrvatskih povijesnih relacija, ističe: „Moć Dositejeva opusa među ilircima je bila u tome što je on svoje spoznaje iskazivao krajnje sugestivno, lapidarno, nerijetko u formi maksima, tako da je bilo moguće izravno ih uvoditi u ideologijski sistem. Dositejev deizam, njegova shvaćanja o Crkvi Hristovoj, koja su u krajnjoj toleranciji prevladavala rimokatoličko-srpskopravoslavne opreke, njegov tako naglašeni antropocentrizam, prije svega u neograničenoj vjeri u mogućnost ljudskog usavršavanja, u svemoć ljudskog odgoja, znanja i čovjekove volje, s njima inherentnim povijesnim optimizmom, savršeno su odgovarali potrebama iliraca u fazi uspona pokreta, do zabrane ilirskog imena 1843.“ (Drago ROKSANDIĆ, „Ilirski Sokrat. Dositej u hrvatskom narodnom preporodu (1835-1848).“, Srpska i hrvatska povijest $i$ „nova historija“(Drago ROKSANDIĆ), Zagreb 1991. 
stvarima. Dositej naime kao i drugi prosvjetitelji njegova vremena na narod gleda racionalno, ne idealizira ga i ne udvara mu se, u njemu vidi istovremeno i vrline i mane. ${ }^{86} \mathrm{U}$ tom stilu opisuje i zemlju Dalmaciju „gdi za kamenita mesta ne imadu ljudi ni zemlje za oranje“, gdje se po nekoliko mjeseci godišnje gladuje, i „s kojekakvim korenjem živi“ ${ }^{87}$ Bukovica, Tromeđa, Podinarje i Zagora najsiromašniji su predjeli kojima je Dositej prolazio na svojim putovanjima, područja su to surova, ali opet „lijepa i zdrava“ („Plavno. Ti znaš kako je ono lepo i zdravo mesto.“), gdje su ljudi navikli na siromašnu i nesigurnu egzistenciju („U studenom Plavnu ne ima ništa van da bi pure od kukuruze ili pulente“), a samo „u gradu, navlastito pri moru, kao što je Skradin, lepše se živi“ ${ }^{88}$

Nije potrebno nagađati jesu li se Fortis i Dositej makar i posredno susreli 1771. godine, iako im se opseg interesa u tom dijelu Dalmacije donekle podudarao. ${ }^{89}$ Zanimljivo je da su životi te dvojice prosvjetitelja i europskih putnika, ${ }^{90}$ rođenih gotovo iste godine, u mnogočemu bili slični. ${ }^{91}$ Premda ne dijele u svemu morlakistički diskurs, zajednička im je osnovna ambivalencija prema morlačkoj sredini. Morlački je svijet za Fortisa arkadijska sredina „plemenitih divljaka“, ali istovremeno i svijet zaostalosti i barbarstva. U dalmatinskim Morlacima pronašao je mitski svijet paralelan onom u keltskoj mitologiji (tobožnjega škotskog barda Ossiana) koja je, premda krivotvorena, sredinom XVIII. stoljeća diljem Europe bila u velikoj modi. ${ }^{92}$ Osijanizam je tako posredno rodio morlakizam. ${ }^{93}$ Fortis u svojem putopisu

$\overline{86}$ „Ništa mi na svetu nije milije i ljubeznije od mojega roda, no koliko ga više ljubim, toliko sam mu više dužan pravdu i istinu predstavljati i govoriti.“ (D. OBRADOVIĆ, Život i priključenija, 84) „Ona naša poslovica ništa ne valja: Kakvi smo, da smo - svoji smo. Namesto ove, ovu drugu valja da uvedeno: Svoji smo, nek smo valjali." (ISTI, Sabrana dela., 341).

87 ISTI, Život i priključenija., 197.

88 Isto, 145.

89 Fortis je prilikom svoga prvog putovanja po Dalmaciji u ljeto 1771. prošao područjem gdje je boravio i Dositej. Od 15. do 31. kolovoza posjetio je Knin, manastir Krku, samostan na Visovcu, Skradin, Pirovac (Zlosela), Vranu, Biograd i Zadar (Žarko MULJAČIĆ, Putovanja Alberta Fortisa po Hrvatskoj i Sloveniji (1765-1791)., Split 1996., 42-53.). Dositej je drugu polovicu 1771. godine proveo dijelom u Skradinu, a potom u Zadru, odakle je ujesen otputovao u Trst, napuštajući zauvijek Dalmaciju.

90 Povlačeći paralele između Dositejeva i Fortisova života i djela, Radovan Kovačević osvrće se i na fenomen putovanja kao ključnog čimbenika u artikulaciji njihovih prosvjetiteljskih stavova: „I u njemu [Fortisu, op. a.] se rano probudila strast za putovanjima. Baš kao i za našeg kaluđera, 'Dositej je putnik ili nije Dositej', i za Fortisa se može reći da ne bi postao ono što jeste da se nije odlučio za odlazak u svet." (Radovan KOVAČEVIĆ, Otkrivanje Mediterana. Dositej Obradović na Sredozemlju 1761-1771., 147). O fenomenu putovanja u svrhu istraživanja i spoznavanja u epohi prosvjetiteljstva pogledati u: Mari-Noel BURGE, „Istraživač.“, Čovek u doba prosvećenosti (priredio Mišel Vovel), Beograd 2006., 266-322.

91 Obojica su rano ostala bez očeva, a majke su im se preudale. Iste 1757. godine kada Dositej odlazi na Frušku goru u manastir Hopovo, Fortis stupa u pustinjački red Sv. Augustina; kod obojice mladih monaha, gotovo u isto vrijeme, dolazi do razočaranja u redovnički život i crkvu općenito, a obojica će kasnije biti izloženi i snažnoj kritici u vlastitim crkvenim krugovima. I Dositej i Fortis morali su otići u inozemstvo jer im domaća sredina nije pružala dovoljno mogućnosti i slobode za naobrazbu i rad u prosvjetiteljskom duhu, proputovavši tako velik dio Europe. Radovan Kovačević ipak opravdano ukazuje i na neke međusobne razlike, nadasve karakterne prirode: „Doduše, postojale su i znatne razlike između ova dva velikana, pre svega u shvatanju sopstvene misije. Dositej je u Dalmaciji, nemajući kome da se žali, štošta podređivao pripremi za odlazak u svet i potrazi za novim, tek naslućenim znanjima. A Fortis, posle neostvarene težnje za katedrom univerziteta u Padovi, razočaran i ojađen, i još više siromašan, odlazi na putovanja po Dalmaciji, da pronađe morlakizam, svoj virtuelni zlatni rudnik. Naročito u Dubrovniku, koji je suviše maštovito opisivao kao Eden, mesto večnog blaženstva, Fortis upada u spletke, podvale levantinskog miljea, pa i u ljubavne avanture, karakteristične za renesansno doba. To Dositej u Dalmaciji, živeći u spartanskim uslovima i u sasvim različitim etičkim sferama, nikada nije sebi dozvolio." (R. KOVAČEVIĆ, Radovan, Otkrivanje Mediterana., 148). Slobodan PROSPEROV NOVAK, Povijest hrvatske književnosti. Svezak I. Raspeta domovina, Split 2004., $217-218$.

93 „Poglavlje o Morlacima - po želji Johna Stuarta - trebalo je podržati i potkrijepiti jednu književnu fikciju o Škotskoj, za koju se Fortisov mecena s toliko gorljivosti zauzimao. Zato je Fortisova slika naše zemlje, ponajprije brdovite dalmatinske unutrašnjosti - još donedavna pod vlašću Turaka - postala prije svega uzorak za osebujna književna 
prikazuje Morlake kao predstavnike najranije („herojske“) faze društvene evolucije, sa svim njihovim vrlinama i manama, kao društvo nepatvorenih pastira i ratnika, čistih $\mathrm{i}$ istinskih nagona, koji žive u skladu s prirodom i koje još nije iskvarila civilizacija - jednostavno, kao svijet koji je unatoč teškim i primitivnim uvjetima života sposoban stvoriti vrijedne plodove duhovnoga života. Za Dositeja pak, kao što je već napomenuto, sjevernodalmatinski svijet čine pošteni i dobri ljudi, koje međutim neprosvijećenost čini zaostalima u i duhovnim i svjetovnim stvarima. Ta neprosvijećenost, oličena u neznanju („nevježestvo“) i praznovjerju (,sujeverije“), uzrok je mnogim štetnim pojavama u međuljudskim odnosima i društvu kao cjelini: predrasudama („predrasuždenije“), mržnjama („mrzost”), neprijateljstvima („vražba“) i svakovrsnim smutnjama („smuštenije“) i podjelama („razdeljenije“). Neograničeno vjerujući u moć razuma i prirodnu dobrotu čovjekovu, Dositej i na primjeru neukih, ali bistrih dalmatinskih gorštaka izlaz iz duhovnoga, ali i materijalnoga „ubožestva“ vidi u odgoju, znanosti i prosvjeti. Taj djelatan pristup dodatno povezuje Dositeja i Fortisa. Dok Dositej teži za opismenjavanjem dalmatinskog stanovništva, Fortis u fiziokratskom duhu iznosi prijedloge za ekonomski napredak Dalmacije. ${ }^{94}$ Obojici su pak korisnost (poleznost) utilitá) za narod ili za državu bili važno idejno načelo i pokretačka snaga.

Iskustvo življenja s Morlacima čini Dositeja bliskim i s još jednim dionikom morlakizma - Ivanom Lovrićem. Taj rođeni Sinjanin, porijeklom iz ugledne morlačke obitelji („dostojne kuće Lovrića“, kako o njima pjeva fra Andrija Kačić Miošić), u želji da ispravi i nadopuni Fortisa, držeći njegovu sliku o Morlacima pretjeranom i uvredljivom, piše čuvene Bilješke (Ossservazioni, Venecija, 1776). ${ }^{95}$ Donoseći neka drukčija zapažanja o Morlacima koja je potaknuo Fortis, u osnovi je međutim dijelio s njim isti diskurs. Lovrić je tako, riječima Slobodana Prosperova Novaka, „upao u zamku Fortisove logike“ otklanjajući neke njegove pogreške te je i ne htijući napisao dopunu knjizi s kojom je polemizirao. ${ }^{96} \mathrm{Na}$ taj je način nesvjesno pridonosio difuziji morlakizma, posebno dodatkom o životu Stanislava (Stanka) Sočivice, ozloglašena i proslavljena hajduka s imperijalne Tromeđe. Lovrićev odnos prema morlačkim sunarodnjacima također je bio ambivalentna karaktera: oni su za njega nekad „Mi“, a katkad „Oni“. Njegovo bogato, ali kratko životno iskustvo (umro je sa svega 23 godine), nadasve školovanje u Veneciji i Padovi, djelovalo je tako da je o neukim i priprostim zemljacima ponekad govorio s pozicije njihovih autopredodžbi, a ponekad opet kao o Drugima, drukčijima od sebe. To ga stavlja u poziciju sličnu Dositeju u njegovu zrelijem razdoblju. Obojica su pak na Morlake gledali kao na jedinstvenu cjelinu, doduše u svojoj konfesionalnoj, „grčko-latinskoj“ dvojnosti, i imali jednaki prosvjetiteljski kritički odmak od svećenstva (kaluđera i franjevaca), koji narodu pune glavu praznovjerjem, drže ga u neznanju i žive mu na grbači. ${ }^{97}$

očitovanja potkraj 18. i u početku 19. stoljeća, uoči evropskog romantizma. Osijanizam je tako posredno rodio morlakizam.“ Josip BRATULIĆ, „Alberto Fortis i njegov put po Dalmaciji.“ Predgovor u: Alberto FORTIS, Put po Dalmaciji., (priredio Josip Bratulić), Zagreb 1984, XXIII.

94 Prema Larryju Wollfu, Fortisovo zanimanje za morlački život i običaje stoji u uskoj vezi s pitanjem ekonomske iskoristivosti toga prekomorskog mletačkog posjeda. Kod Fortisa se naime, tvrdi isti autor, pojavila nova ideja „imperijalnog patriotizma" temeljena na otkriću i razvoju gospodarskih resursa, čime je, između ostalog, Dalmaciju promatrao ne samo u prirodoznanstvenom smislu, već i iz perspektive nacionalne ekonomije (L. WOLLF,. Venice and the Slavs. The Discovery of Dalmatia in the Age of Enlightenment, 76-125.).

95 O Ivanu Lovriću (1754-1777) vidi: Ivan Lovrić i njegovo doba. Referati i saopćenja sa znanstvenog skupa. Zbornik Cetinske krajine, knjiga I. (ur. Stjepan Gunjača i ostali), Sinj 1979.

96 S. PROSPEROV NOVAK, Povijest hrvatske književnosti. Svezak I. Raspeta domovina., 219.

97 „Navlastito u Dalmaciji, gdi za kamenita mesta ne imadu ljudi ni zemlje za oranje, gdi više nego polovina naroda po nekoliko meseci gladuje i s kojekakvim korenjem živi: kad mu ono malo žita dospe, navale ne samo domaći nego i 


\section{IV.}

Dositej u Dalmaciji ni u kojem slučaju nije bio putnik u nepoznatome prostoru, njegov boravak u toj pokrajini teško da bi se mogao opisati kao „stranstvovanje“. U njoj je vidio udaljenu pokrajinu svoga razdijeljenog „otečestva“, u početku samo kao prostor pravoslavnih mu istovjernika, a kasnije i kao šire narodnosne, istojezične zajednice. Ta je pokrajina bila samo jedna, ali važna stanica na njegovu putu otkrivanja čovjeka i društva, vlastita naroda kao i samoga sebe; ondje je počeo stjecati, kantovski rečeno, „zrelost“ koja je odbacivala povijesno stvorene suprotnosti i vjersko-tradicionalne okvire života i vodila ga prema filozofskoj misli o slobodi mišljenja, o potrebi vjerske tolerancije, ljudske jednakosti i pravde, o zemaljskoj sreći i životnom idealu u radu i kreposti te, konačno, o razumu kao najvećem autoritetu. Mirnim, blagim i dobronamjernim načinom opisao je svoje dalmatinske, najvećma morlačke suvremenike, i uspješno ocrtao društvene i kulturne prilike toga vremena i prostora. Kao glavni problem uvijek je isticao neposredni život i potrebu da se podigne opća razina svijesti i obrazovanja. Upravo je tako u zaostaloj dalmatinskoj sredini i osjetio snažnu potrebu da počne aktivno djelovati na „opšte dobro“ i „polzu” narodu i pojedincu. ${ }^{98}$

\section{Dalmatia in eyes of Dositej OBRadović and PHENOMENON OF 'MORLAKISM'}

Using theoretical framework of historical imagology, the author analyses D. Obradovićs perceptions of Dalmatia and of Morlaks inhabiting its hinterlands. Influences of then prevailing Enlightenment philosophy and specific socio-cultural contexts of „Morlak“ Dalmatia (especially its Orthodox Serb element) both intersected (or clashed) in the person of D.O. The central problem analysed here is how this reflected on images and perceptions of the „people“ and the "land“ created by Dositej. There are two periods to consider; "young", when he was still under influence of church traditions while in Dalmatia, and „mature“ when ideas of the Enlightenment took over. Most of his perceptions originated from mature period and were integral to his fully rounded rationalist mindset. Multi-layered nature of views on Dalmatia reflects in criticisms directed against 3 sorts of phenomena. First, superstitions and traditions of Morlak people, second, religious culture and mutual bigotry between Morlaks following „greek“ and „latin“ religious traditions, and, lastly, the role of traditions in the cultural practices and identity forming. Instead of following prevailing literary discourses of „morlakism“, he does not „discover“ exotic people or „noble savages“, but fair and noble if rather simple people. He sees them as his („Slavoserbs"), and it is necessary to uplift

sa strana kaluđeri i fratri, i s guvna razgrabe mu hranu. Kad se vuna striže, eto ti kaluđera! Kad maslo i sir pastiri, i od svojih usta šteđeni, za zimu sabiraju, eto ti njih! Kad se vinogradi beru i masline kupe, navale sa sve četiri strane! Kad ljudi po običaju svoga sveca slave i gtada sebe mlogi zatiru, vidiš istom po čopor kaluđera, pak da hoćedu samo da jedu i piju kao i ostali ljudi, pak da idu svojim putem, neka bi! Ali oni tada zapisuju, nemilostivo i bestidno ištu salandare, proskompidije, pomenike, vola, kravu, a do siromaha ovcu, jare ili ako ništa - čarape, on mora što otkinuti, da mu nije zaludu put." (D. OBRADOVIĆ, Sabrana dela., 548).

„Razmišljajući neprestano o ovima veštima (stvarima, op.a.), spomenem se jošte u Dalmaciji začetoga želanija i namjerenija da je krajnje potrebe i nužde delo na opštem narodnjem jeziku što napisati i izdati. Ja sam često pred očima imao kakvu su buru i metavicu na sebe svi oni privlačili koji su se usudili najpre i najpre podobna predstavljenija narodu činiti. No mora se kadgod ko jednaput naći. 'Ajde, u ime Božije, nek se počne!'“ (ISTI, Život i priključenija., 173). 
them in the spirit of Enlightenment. What links him the most to „morlakist“ discourse is moderate idealisation. To him they are just and fair people; however, their superstitious and ignorant nature makes them backward. Therefore, he has coflicting views of Morlaks. At one time he describes them as his compatriots (we-relationship), at other he may consider them as Others, different from him (they-relationship), especially when criticising superstitions and traditions. Religious bigotry is a special problem, but clergy is the source of it according to him. That makes him close to Fortis and Lovrić in views.

Keywords: Dositej Obradović, Enlightenment, historical imagology, Venetian Dalmatia, Morlaks, morlakism.

\section{$\cos$}

\section{Popis korištene literature}

Lujo BAKOTIĆ, Srbi u Dalmaciji od pada Mletačke Republike do ujedinjenja, Beograd 1938.

Zrinka, BLAŽEVIĆ, „Ilirski ideologem u djelima Andrije Kačića Miošića.“ Fra Andrija Kačić Miošić i kultura njegova doba (ur. Dunja Fališevac), Zagreb 2007.

Dušan BERIĆ, „Boravak Dositeja Obradovića u Dalmaciji“, Književni Jadran, V/1951.

Dušan, BERIĆ, „Dositej Obradović u Dalmaciji”, Zadarska revija, 6/1961.

Brankovo kolo. XII/1911; XIII/1911; XVI/1911. (prilozi Vatroslava Jagića, Tihomira Ostojića, Radivoja Vrhovca, Milana Rešetara, Dimitrija Ruvarca, Frana Ilešića, Milana Krestića, Đure Šurmina, Milana Ševića, Vase Stajića i Ivana Prijatelja).

Mari-Noel BURGE, „Istraživač.“, Čovek u doba prosvećenosti (priredio Mišel Vovel), Beograd 2006., 266-322.

Marko CAR, „Dositej i Tomazeo”, Letopis Matice srpske, VI/1911.

Sima ĆIRKOVIĆ, Srbi među evropskim narodima, Beograd 2004.

Jovan DERETIĆ, Dositej i njegovo doba, Beograd 1969.

Vladan, DESNICA, „Jedan pogled na ličnost Dositeja Obradovića”, Magazin severne Dalmacije, 1934.

Davor DUKIĆ, „Predgovor: O imagologiji.”, Kako vidimo strane zemlje. Uvod u imagologiju. (priredili: Davor Dukić, Zrinka Blažević, Lahorka Plejić Poje, Ivana Brković), Zagreb 2009., 5-22.

Tihomir R. ĐORĐEVIĆ, „Dositej Obradović i folklorno gradivo.”, Spomenica Dositeja Obradovića. (Skupina autora), Beograd 1911., 38-52.

Milorad EKMEČIĆ, Stvaranje Jugoslavije 1790-1918. 1. Beograd 1989.

Alberto FORTIS, Put po Dalmaciji., (priredio Josip Bratulić), Zagreb 1984.

Stjepan GUNJAČA, ur.; et. al., Ivan Lovrić i njegovo doba. Referati i saopćenja sa znanstvenog skupa. Zbornik Cetinske krajine, knjiga I., Sinj 1979.

Vladimir GVOZDEN, „Polazišta i ciljevi imagološkog proučavanja književnosti.“, Zbornik Matice srpske za književnost i jezik, Vol. 49/2001., br. 1-2, 212-224.

Josip HORVAT, Ljudevit Gaj. Njegov život, njegovo doba, Zagreb 1970.

Dušan IVANIĆ, Književnost Srpske Krajine, Beograd 1998.

Pavel IVIĆ, Pregled istorije srpskog jezika, Sremski Karlovci-Novi Sad 1998.

Marko JAČOV, Venecija i Srbi u Dalmaciji u XVIII. veku, Šibenik 1987. 
Stanko KORAĆ, „Dositej Obradović ili put do mišljenja“, Zbornik radova o povijesti i kulturi srpskog naroda u Socijalističkoj Republici Hrvatskoj. Knjiga 2 (ur. Vasilije Krestić), Zagreb 1989., 7-50.

Mita KOSTIĆ, Dositej Obradović u istorijskoj perspektivi XVIII. i XIX. veka. SANU, Knjiga 190/2, Beograd 1952.

Ivan KOVAČEVIĆ, Istorija srpske etnologije. I. Prosvetiteljstvo. Beograd 2001.

Radovan KOVAČEVIĆ, Otkrivanje Mediterana. Dositej Obradović na Sredozemlju 1761.-1771., Beograd 2007.

Marko KRSMANOVIĆ, „Robinson u nas [Povodom stopedesetogodišnjice prvog srpskog prevoda]", Nastava jezika i književnosti u srednjoj školi, God. I, sv. 1-2/1950.

Herta KUNA, Jezičke karakteristike književnih djela Dositeja Obradovića, Djela ANUBiH, knjiga XXXVI, Sarajevo 1970.

Milorad S. KURAICA, Dositej u Dalmaciji. Subotica 2011.

Borivoje MARINKOVIĆ, „Tri priloga proučavanju Dositeja Obradovića: Dositej i Gerasim Zelić." Kovčežić, III/1960.

Svetozar MATIĆ, „Dositejeve neobjavljene propovedi”, Glasnik Istorijskog društva u Novom Sadu, III/1930.

Nikodim MILAŠ, Documenta spectantia historiam orthodoxae Dalmatiae et Istriae a XV usque XIX saeculum. Vol. I, Jaderae 1899.

Nikodim MILAŠ, Pravoslavna Dalmacija, Novi Sad 1901.

Vaso MILIĆEVIĆ, „Dositejev primer“, Zbornik radova o povijesti i kulturi srpskog naroda u Socijalističkoj Republici Hrvatskoj. Knjiga 2 (ur. Vasilije Krestić), Zagreb 1989., 51-66.

Ksota MILUTINOVIĆ, Vojvodina i Dalmacija 1760.-1914, Novi Sad 1973.

Sima MILUTINOVIĆ, Otziv na poziv 1839. god., Pešta 1839.

Aleksandar MLADENOVIĆ, „Grafijska i jezička ispitivanja rukopisa Dositeja Obradovića“, Kovčezić, IV/1961., 135-161.

Žarko MULJAČIĆ, Putovanja Alberta Fortisa po Hrvatskoj i Sloveniji (1765-1791)., Split 1996.

Žarko MULJAČIĆ, Fortisološke studije, Split 2011.

Stojan NOVAKOVIĆ, „Dositej Obradović i srpska kultura.” Spomenica Dositeja Obradovića. (Skupina autora), Beograd 1911., 5-37.

Dositej OBRADOVIĆ, Dela Dositeja Obradovića. Peto, državno izdanje. (ur. Jovan Skerlić; Milutin Dragutinović; Miloš Ivković), Beograd 1911.

Dositej OBRADOVIĆ, Pisma Haralampiju, Život i priklučenija, Beograd 1975.

Dositej OBRADOVIĆ, Život i priključenija, Beograd 1989.

Dositej OBRADOVIĆ, Sabrana dela Dositeja Obradovića. (ur. Mirjana D. Stefanović), knjiga 6, Beograd 2008.

Milorad PAVIĆ, Istorija srpske književnosti baroknog doba, Beograd 1970.

Milorad PAVIĆ, Istorija srpske književnosti klasicizma i predromantizma. Klasicizam, Beograd 1979.

Milorad PAVIĆ, Radanje nove srpske književnosti, Beograd 1983.

Milorad PAVIĆ, „Književni tokovi srpskog predromantizma“ (http://www.rastko.org.yu/knjizevnost/pavic/predromantizam/mpavic-predromantizam-1html).

Milenko PEKIĆ, Dositej i Zadar. Novi Sad 1989.

Danko PERIĆ. Plavno - monografija. Beograd, 2008.

Dušan PETRANOVIĆ, Dositije Obradović. Spomenica o posmrtnoj mu stogodišnjici. Dubrovnik 1911. 
Slobodan PROSPEROV NOVAK, Povijest hrvatske književnosti. Svezak I. Raspeta domovina, Split 2004.

Nino RASPUDIĆ, Jadranski (polu)orijentalizam. Prikazi Hrvata u talijanskoj književnosti, Zagreb 2010.

Drago ROKSANDIĆ, Srbi u Hrvatskoj od 15. stoljeća do naših dana, Zagreb 1991.

Drago ROKSANDIĆ, Srpska i hrvatska povijest i „nova historija“, Zagreb 1991.

Jovan SKERLIĆ, Istorijski pregled srpske štampe 1791-1911. Sabrana dela VIII, Beograd 1960.

Jovan SKERLIĆ, Istorija srpske književnosti u XVIII. veku, Beograd 1966.

Mirjana D. STEFANOVIĆ, Leksikon srpskog prosvetiteljstva. Beograd 2009.

Mirjana D. STEFANOVIĆ, „Čemu istoriografija u 18. stoleću.“, Istraživanja (Novi Sad), br. 21/2010.

Miodrag V. STOJANOVIĆ, Dositej i antika, Beograd 1971.

Marko ŠARIĆ, „Bunjevci u ranome novom vijeku: postanak i razvoj jedne predmoderne etnije“, $\check{Z}$ vjeti na Krivom Putu, svezak I. (ur. Milana Černelić, Marijeta Rajković, Tihana Rubić), Zagreb 2008., 15-43.

Marko ŠARIĆ, „Predmoderne etnije u Lici i Krbavi prema popisu iz 1712./14.“, Identitet Like: korijeni i razvitak. Knjiga I. (ur. Željko Holjevac), Zagreb-Gospić 2009., 327-384.

Marko ŠARIĆ, „Planine i morlački svijet u Dalmaciji: ekohistorijski osvrt“, Ekonomska i ekohistorija: časopis za gospodarsku povijest i povijest okoliša, Vol. 6, No. 1/2010., 55-94.

Jaroslav ŠIDAK, „O uredniku i značenju ilirskog Branislava (1844-45).“, Historijski zbornik, XIV/1961.

Jaroslav ŠIDAK, Hrvatski narodni preporod. Ilirski pokret, Zagreb 1990.

Ferdo ŠIŠIĆ, Južnoslovenska misao. Istorija ideje jugoslovenskog narodnog ujedinjena i oslobodenja od 1790-1918., Beograd 1937.

Đuro ŠURMIN, „Dositije Obradović u Dalmaciji“, Jug, br. 4/1911.

Alen TAFRA, „Dodir Mediterana i Istočne Europe u svjetlu 'filozofske geografije'.", Metodički ogledi, $18-1 / 2011$.

Rajko VESELINOVIĆ, „Srbi pod mletačkom vlašću. (Srbi u Dalmaciji).“, Istorija srpskog naroda. Četvrta knjiga, drugi tom. Srbi u XVIII. veku (ur. Slavko Gavrilović, et. al.), Beograd, 1986., 7-66.

Dragić VITOŠEVIĆ, Do Evrope i natrag I, Gornji Milanovac 1987.

Josip VRANDEČIĆ i Miroslav BERTOŠA, Dalmacija, Dubrovnik i Istra u ranome novom vijeku, Zagreb 2007.

Larry WOLFF, Inventing Eastern Europe: The Map of Civilization on the Mind of the Enlightenment, Stanford CA 1994.

Larry WOLFF, Venice and the Slavs. The Discovery of Dalmatia in the Age of Enlightement, Stanford CA 2001. 